\title{
Dopamine-Dependent Tuning of Striatal Inhibitory Synaptogenesis
}

\author{
Darren Goffin, ${ }^{1}$ Afia B. Ali, ${ }^{1}$ Nazir Rampersaud, ${ }^{1}$ Alexander Harkavyi, ${ }^{1}$ Celine Fuchs, ${ }^{1}$ Peter S. Whitton, ${ }^{1}$ \\ Angus C. Nairn, ${ }^{2}$ and Jasmina N. Jovanovic ${ }^{1}$ \\ ${ }^{1}$ Department of Pharmacology, The School of Pharmacy, University of London, Brunswick Square, London WC1N 1AX, United Kingdom, and \\ ${ }^{2}$ Department of Psychiatry, Division of Molecular Psychiatry, Yale University School of Medicine, Ribicoff Research Facilities, Connecticut Mental Health \\ Center, New Haven, Connecticut 06508
}

Dopaminergic projections to the striatum, crucial for the correct functioning of this brain region in adulthood, are known to be established early in development, but their role is currently uncharacterized. We demonstrate here that dopamine, by activating $\mathrm{D}_{1}$ - and/or $\mathrm{D}_{2}$-dopamine receptors, decreases the number of functional GABAergic synapses formed between the embryonic precursors of the medium spiny neurons, the principal output neurons of the striatum, with associated changes in spontaneous synaptic activity. Activation of these receptors reduces the size of postsynaptic $\mathrm{GABA}_{\mathrm{A}}$ receptor clusters and their overall cell-surface expression, without affecting the total number of clusters or the size or number of GABAergic nerve terminals. These changes result from an increased internalization of $\mathrm{GABA}_{\mathrm{A}}$ receptors, and are mediated by distinct signaling pathways converging at the level of $\mathrm{GABA}_{\mathrm{A}}$ receptors to cause a transient PP2A/PP1-dependent dephosphorylation. Thus, tonic $\mathrm{D}_{1}$ - and $\mathrm{D}_{2}$-receptor activity limits the extent of collateral inhibitory synaptogenesis between medium spiny neurons, revealing a novel role of dopamine in controlling the development of intrinsic striatal microcircuits.

\section{Introduction}

The striatum, as the central part of the basal ganglia, integrates excitatory inputs from the cortex and thalamus with dopaminergic inputs from the substantia nigra pars compacta (SNpc), and sends projections to the output nuclei. It is composed primarily of GABAergic medium spiny projection neurons (95-98\%), and a small number of GABAergic interneurons and cholinergic neurons ( $\sim 5 \%$ of all neurons) (Tepper and Bolam, 2004). Inhibition of medium spiny neurons is largely intrinsic to the striatum and occurs primarily via a feedforward mechanism mediated by the interneurons (Tepper and Bolam, 2004; Mallet et al., 2005), and to some extent by a feedback mechanism between projection neurons (Guzmán et al., 2003; Taverna et al., 2008). The essential molecular mediators of both mechanisms are $\mathrm{GABA}_{\mathrm{A}}$ receptors, members of a diverse family of heteropentameric GABA-gated chloride channels, which can be assembled from seven classes of homologous subunits: $\alpha(1-6), \beta(1-3), \gamma(1-3), \delta, \varepsilon, \theta$, and $\pi$ (Whiting, 2003). GABA $\mathrm{A}$ receptors are highly concentrated at synaptic sites apposed to presynaptic GABA-releasing terminals in the striatum (Fujiyama et al., 2000), and are likely to be dy-

Received Sept. 7, 2009; revised Jan. 8, 2010; accepted Jan. 15, 2010.

This work was supported by the Biotechnology and Biological Sciences Research Council UK New Investigator Grant BB/C507237/1 (to J.N.J.) and a Novartis-funded PhD studentship (to D.G.). We thank Dr. Tom McAvoy, Laura Maruca, and Anya Sihra-Jovanovic for technical assistance, and Dr. Talvinder Sihra for critical reading of this manuscript.

Correspondence should be addressed to Dr. Jasmina N. Jovanovic, Department of Pharmacology, The School of Pharmacy, University of London, Brunswick Square, London WC1N 1AX, UK. E-mail: jasmina.jovanovic@ pharmacy.ac.uk.

DOI:10.1523/JNEUROSCI.4411-09.2010

Copyright $\odot 2010$ the authors $\quad 0270-6474 / 10 / 302935-16 \$ 15.00 / 0$ namically regulated by the lateral migration to extrasynaptic sites (Thomas et al., 2005), internalization and reinsertion (Kittler et al., 2000, 2004), and direct phosphorylation (Brandon et al., 2002; Jovanovic et al., 2004) as reported in other brain regions.

The essential role of dopamine in a wide range of psychomotor functions of the adult striatum has been extensively characterized in both health and disease, and shown to be mediated through the activation of $\mathrm{D}_{1}$ - and $\mathrm{D}_{2}$-like dopamine receptors $\left(D_{1}\right.$ Rs and $D_{2}$ Rs) (Seeman and Van Tol, 1994). Thus, dopamine receptors regulate the activity of striatal neurons (Aosaki et al., 1998; Bracci et al., 2002), GABAergic currents (Yan and Surmeier, 1997; Flores-Hernandez et al., 2000), and glutamatergic synapse numbers (Day et al., 2006). In contrast, the role of dopamine in the developing striatum is unknown despite the evidence that dopaminergic inputs from the SNpc are formed as early as embryonic day 12 (E12) in rats (Voorn et al., 1988; Gates et al., 2006). Nevertheless, a developmental role for dopamine has been suggested by observations following in utero exposure to cocaine, which, via activation of dopamine receptors (Jones et al., 2000; Stanwood and Levitt, 2007), has profound effects on the development of dendrites (Jones et al., 1996; Levitt et al., 1997) and expression of $\mathrm{GABA}_{\mathrm{A}}$ receptors (Lu et al., 2009). Given that embryonic striatal neurons express both $\mathrm{D}_{1}$ Rs and $\mathrm{D}_{2}$ Rs (Aizman et al., 2000), we sought to assess whether these receptors regulate GABAergic synaptogenesis in the developing striatum.

We demonstrate that dopamine receptor activity decreases the number of GABAergic synapses formed between striatal neurons in vitro, by causing a reduction in the size of $\mathrm{GABA}_{\mathrm{A}}$ receptor clusters and their overall cell-surface expression. These changes are mediated by distinct $\mathrm{D}_{1} \mathrm{R}$ and $\mathrm{D}_{2} \mathrm{R}$ signaling pathways con- 
verging at the level of $\mathrm{GABA}_{\mathrm{A}}$ receptors to trigger their transient PP2A/PP1-dependent dephosphorylation. Thus, by altering the levels of cell-surface expression of $\mathrm{GABA}_{\mathrm{A}}$ receptors, dopamine exerts a powerful control of inhibitory synaptogenesis in the developing striatum.

\section{Materials and Methods}

Immunohistochemistry. Whole-brain specimens were isolated from E17 Sprague Dawley rats and fixed overnight in $4 \%$ paraformaldehyde, $0.1 \%$ glutaraldehyde, and $0.2 \%$ saturated picric acid solution in $0.1 \mathrm{M}$ phosphate buffer (PB), $\mathrm{pH} \mathrm{7.2,} \mathrm{at} 4^{\circ} \mathrm{C}$. For cryoprotection, brains were immersed in increasing concentrations of sucrose/PBS (10\%, 20\%, and $30 \%$ ) until submerged, at $4^{\circ} \mathrm{C}$. Brain specimens were frozen, and $20 \mu \mathrm{m}$ sections were cut through the midbrain-hindbrain region. Sections were washed with PBS and incubated with $0.3 \mathrm{~m}$ glycine/PBS to quench PFA. For permeabilization and reduction of nonspecific binding, sections were incubated in $1 \%$ BSA/ $0.1 \%$ Triton X-100/PBS for $30 \mathrm{~min}$. Sections were incubated with a rabbit anti-tyrosine hydroxylase antibody $(1: 1000$ dilution, Merck Biosciences), or mixture of mouse anti- $\mathrm{D}_{1} \mathrm{R}$ (1:100 dilution, Abcam) and rabbit anti- $\mathrm{D}_{2} \mathrm{R}(5 \mu \mathrm{g} / \mathrm{ml}$, Millipore) antibodies in PBS overnight at $4^{\circ} \mathrm{C}$. Primary antibodies were visualized after staining with the appropriate goat anti-rabbit and anti-mouse IgGs conjugated to Alexa555 and Alexa488, respectively ( $3 \mu \mathrm{g} / \mathrm{ml}$, Millipore Bioscience Research Reagents), in 1\% BSA/PBS for $60 \mathrm{~min}$. Sections were washed and coverslips mounted using Vectashield (Vector). Immunoreactivity was visualized using laser scanning confocal microscope (Zeiss LSM 510 Meta) with $\times 5$ objective or $\times 63$ oil-immersion objective.

HPLC analysis of tissue dopamine levels. Embryonic striata were promptly dissected and weighed before being flash-frozen and stored at $-80^{\circ} \mathrm{C}$. Individual tissue samples were then placed in ice-cold PBS and homogenized. All homogenates were treated with $0.1 \mathrm{M}$ perchloric acid $(1: 10, \mathrm{w} / \mathrm{v})$ containing ascorbic acid $(0.2 \mu \mathrm{M})$ and EDTA $(0.2 \mu \mathrm{M})$, to precipitate cell debris. These were then centrifuged at $13,000 \times g$ for 15 min at $4^{\circ} \mathrm{C}$. The supernatant was passed through a syringe filter $(10 \mu \mathrm{m}$ pore size), and whole-tissue dopamine levels were estimated using HPLC with electrochemical detection (Biggs et al., 1992). Dopamine peak areas were quantified using an external standard method, and dopamine levels expressed as amount of dopamine in nanomoles per milligram of total protein content, with protein levels measured using BCA assay (Thermo Fisher Scientific).

Cell cultures. Primary striatal neuronal cultures were prepared as described previously (Ventimiglia and Lindsay, 1998) with minor modifications. Briefly, striata were dissected from E16-E17 Sprague Dawley rats, dissociated by trituration in $\mathrm{Ca}^{2+}$ - and $\mathrm{Mg}^{2+}$-free HEPES-buffered saline solution (HBSS; Invitrogen), plated at a density of 100,000 cells per $\mathrm{cm}^{2}$ in Neurobasal medium, containing B27 supplement, glutamine (2 mM), penicillin (100 U), streptomycin $(100 \mu \mathrm{g})$, and glucose (6 $\mathrm{mm}$; all from Invitrogen) on either $0.1 \mathrm{mg} / \mathrm{ml}$ poly-D-lysine-coated culture dishes or $0.1 \mathrm{mg} / \mathrm{ml}$ poly-L-lysine-coated glass coverslips. Cultures were incubated in a humidified $37^{\circ} \mathrm{C} / 5 \% \mathrm{CO}_{2}$ incubator for 7 or $14 \mathrm{~d}$ before experimentation.

Immunocytochemistry. Striatal neurons cultured at a density of 100,000 cells $/ \mathrm{cm}^{2}$ were treated with vehicle, the $\mathrm{D}_{1} \mathrm{R}$ agonist SKF-38393 (1 nM), or the $\mathrm{D}_{2} \mathrm{R}$ agonist quinpirole ( $100 \mathrm{~nm}$; both from Tocris Bioscience) for $72 \mathrm{~h}$ (from 4 to $7 \mathrm{~d}$ in vitro, DIV) or $7 \mathrm{~d}$ (from 7 to $14 \mathrm{DIV}$ ), before fixation with $4 \%$ paraformaldehyde/ $4 \%$ sucrose/PBS for $15 \mathrm{~min}$. Cultures were washed and incubated with $1 \%$ BSA/0.5\% Triton X-100/PBS for 30 min to permeabilize cells and reduce nonspecific binding. Cultures were incubated with mouse anti- $\mathrm{D}_{1} \mathrm{R}$ (1:100 dilution, Abcam) and rabbit anti$\mathrm{D}_{2} \mathrm{R}\left(5 \mu \mathrm{g} / \mathrm{ml}\right.$, Millipore) antibodies in PBS overnight at $4^{\circ} \mathrm{C}$. For analysis of GABAergic synapses, cultures were first incubated with the $\mathrm{GABA}_{\mathrm{A}}$ receptor $\beta_{2 / 3}$ subunit-specific primary antibody (MAB341, bd17 clone, $10 \mu \mathrm{g} / \mathrm{ml}$, Millipore Bioscience Research Reagents) in 1\% BSA/PBS overnight $(14-16 \mathrm{~h})$ at $4^{\circ} \mathrm{C}$ without permeabilization. Cultures were then washed with PBS and cells permeabilized with $0.5 \%$ Triton X-100/PBS for $30 \mathrm{~min}$, followed by incubation with $1 \%$ BSA/PBS for $30 \mathrm{~min}$ to block nonspecific binding. Cultures were incubated with rabbit anti-vesicular inhibitory amino acid transporter (VIAAT) antibody [1:1000, kindly provided by Dr. A. Dumoulin and Prof. A. Triller, Inserm U497, Ecole Normale Supérieure, Paris, France (Dumoulin et al., 2000)] or glutamic acid decarboxylase (GAD) 65 (1:1000, Millipore Bioscience Research Reagents) in 1\% BSA/PBS for $60 \mathrm{~min}$. Primary antibodies were visualized after staining with the appropriate goat anti-mouse and anti-rabbit IgG conjugated to Alexa555 and Alexa488, respectively ( $3 \mu \mathrm{g} / \mathrm{ml}$, Millipore Bioscience Research Reagents), in 1\% BSA/PBS for $60 \mathrm{~min}$. Cultures were washed and coverslips mounted using Vectashield (Vector). Immunoreactivity was visualized using laser scanning confocal microscope (Zeiss LSM 510 Meta) with a $\times 63$ oil-immersion objective. In each image, laser light levels and detector gain and offset were adjusted to avoid any saturated levels.

Quantification of punctum area, number, and colocalization. For each treatment, a minimum of 6-10 randomly selected neurons were examined in at least three independent experiments. For these experiments, the number, area, and colocalization of puncta were determined from confocal images using the LSM5 Image program. Immunoreactive puncta were defined as immunoreactivity $>0.1 \mu \mathrm{m}^{2}$ present along the first $20 \mu \mathrm{m}$ length of primary processes (Yu et al., 2007). Threshold for each channel in each image was calculated as the mean pixel intensity for the entire image plus two SDs above the mean. Puncta colocalization in two different fluorescence channels was determined by overlaying the images. A punctum in the red channel was considered to colocalize with a punctum in the green channel, resulting in a yellow color, when $\sim 50 \%$ or more of the surface of one punctum overlapped with the other punctum. Colocalization was analyzed by determining the percentage of individual $\beta 2 / 3$ subunit-positive puncta along the first $20 \mu \mathrm{m}$ length of primary processes that were in close apposition to (and thus partially overlap with) VIAAT-1 or FM1-43FX-immunoreactive puncta. Values are expressed as mean \pm SEM (number of cells). Statistical analysis was performed using a two-tailed $t$ test (Graphpad Prism 4.0).

FM1-43FX uptake. To assess the functionality of GABAergic neurons, we determined the uptake of the aldehyde-fixable styryl dye FM1-43FX (Invitrogen) (Sara et al., 2002; Brumback et al., 2004). Uptake of FM1$43 \mathrm{FX}$ was performed as previously described with some minor modifications (Ting et al., 2006). Following treatment with dopamine receptor agonists as described in the previous section, cells were briefly washed twice with buffer A (mM: $149 \mathrm{NaCl}, 4 \mathrm{KCl}, 1.5 \mathrm{CaCl}_{2}, 1.5 \mathrm{MgCl}_{2}, 10$ glucose, and 10 HEPES, pH 7.4). Cultures were then incubated at $37^{\circ} \mathrm{C}$ with $100 \mu \mathrm{M}$ bicuculline, $100 \mu \mathrm{M}$ picrotoxin, $50 \mu \mathrm{M}$ D-AP5, and $10 \mu \mathrm{M}$ CNQX (all from Tocris Bioscience) diluted in buffer A. Cultures were further incubated in $60 \mathrm{mM} \mathrm{K}^{+}$solution (in mM: $69 \mathrm{NaCl}, 60 \mathrm{KCl}, 1.5$ $\mathrm{CaCl}_{2}, 1.5 \mathrm{MgCl}_{2}, 10$ glucose, and 10 HEPES, pH 7.4) containing FM143FX $(10 \mu \mathrm{M})$ for $2 \mathrm{~min}$. Excess styryl dye was effectively removed by washing three times in cold buffer $\mathrm{A}\left(4^{\circ} \mathrm{C}\right)$ for $1 \mathrm{~min}$, followed by washing twice with ADVASEP-7 (500 $\mu \mathrm{M}$, Sigma-Aldrich) for 2 min (Kay et al., 1999). Cultures were subsequently washed in buffer A with a low concentration of $\mathrm{K}^{+}$to remove FM1-43FX/ADVASEP-7 at $4^{\circ} \mathrm{C}$ without causing exocytosis of vesicles loaded with FM1-43FX dye. Cells were fixed in $4 \%$ paraformaldehyde/ $4 \%$ sucrose/PBS and processed for immunocytochemistry using anti- $\beta 2 / 3$ antibody, followed by goat antimouse IgG conjugated to Alexa555 $(3 \mu \mathrm{g} / \mathrm{ml})$ as described above. Immunoreactivity was visualized using a Zeiss LSM 510 Meta laser scanning confocal microscope with a $\times 63$ oil-immersion objective.

Electrophysiology. Whole-cell recordings were made from striatal neurons in culture, treated with the vehicle, SKF-38393 (1 nM), or quinpirole

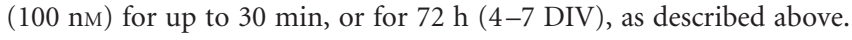
Neurons were visualized using videomicroscopy under near-infrared differential interference contrast (DIC) illumination. Experiments were conducted at $20-22^{\circ} \mathrm{C}$. Patch pipettes (resistance $8-10 \mathrm{M} \Omega$ ) were pulled from borosilicate glass tubing and filled with an internal solution containing the following (in $\mathrm{mm}$ ): $144 \mathrm{~K}$-gluconate, $3 \mathrm{MgCl}_{2}, 0.2 \mathrm{EGTA}, 2$ $\mathrm{Na}_{2}$-ATP, $0.2 \mathrm{Na}_{2}$-GTP, and 10 HEPES, pH 7.2-7.4, 300 mOsm. Spontaneous activity of the neurons was recorded in current-clamp mode (SEC 05L/H, npi electronics) in the presence of TTX (1 $\mu \mathrm{M})$, D-AP5 (50 $\mu \mathrm{M})$, and CNQX (20 $\mu \mathrm{M}$, all from Tocris Bioscience). Synaptic potentials recorded were amplified, low-pass filtered at $2 \mathrm{kHz}$, and digitized at 5 $\mathrm{kHz}$ using a CED 1401 interface and data acquisition program, Signal 4.04 (Cambridge Electronic Design). Electrophysiological recordings 
were later analyzed offline using Signal. Individual sweeps were observed manually and measurable IPSPs were taken from values $>0.05 \mathrm{mV}$ in peak amplitudes. Miniature IPSP amplitudes (measured from the baseline to the peak of the IPSP) and rise times (10-90\%) were measured from individual synaptic events. Average amplitudes are given as mean \pm SD obtained from $100-250$ frames of $1 \mathrm{~s}$ duration. Events $<0.05 \mathrm{mV}$ were related to the baseline noise without any measurable amplitudes or rise times. The data illustrated in Figure 3 are individual single sweep raw data that have not been smoothed, and illustrate a high signal-to-noise ratio.

Internalization assay. Cell-surface receptors were tagged in living cultured neurons with the primary antibody against $\beta_{2 / 3}$ subunits as described previously (van Rijnsoever et al., 2005). Briefly, coverslips were incubated with ice-cold buffer A (in mM: $150 \mathrm{NaCl} ; 3 \mathrm{KCl} ; 2 \mathrm{MgCl}_{2} ; 10$ HEPES, pH 7.4; and 5 glucose), containing $0.35 \mathrm{~m}$ sucrose for $5 \mathrm{~min}$ to inhibit receptor internalization, followed by incubation with mouse anti$\beta_{2 / 3}$ antibody (MAB341, $10 \mu \mathrm{g} / \mathrm{ml}$, Millipore Bioscience Research Reagents) for $60 \mathrm{~min}$ at $4^{\circ} \mathrm{C}$ in buffer A containing $0.35 \mathrm{~m}$ sucrose, $1 \mathrm{~mm}$ EGTA, and $1 \%$ BSA. Excess antibody was removed by washing in the same medium. Cultures were returned to the incubator $\left(\right.$ at $\left.37^{\circ} \mathrm{C}\right)$ in buffer A containing $1 \mathrm{~mm} \mathrm{CaCl}_{2}, 5 \mathrm{~mm}$ glucose, and $5 \mu \mathrm{g} / \mathrm{ml}$ leupeptin in the absence or presence of SKF-38393 (1 nM) or quinpirole (100 nM) for $30 \mathrm{~min}$ to allow internalization of the tagged $\beta_{2 / 3}$ subunit-containing $\mathrm{GABA}_{\mathrm{A}}$ receptors. Cultures were then fixed for 15 min using $4 \%$ paraformaldehyde $/ 4 \%$ sucrose/PBS, extensively washed with PBS, and incubated in $1 \% \mathrm{BSA} / \mathrm{PBS}$ for $30 \mathrm{~min}$ to reduce nonspecific binding. To label $\mathrm{GABA}_{\mathrm{A}}$ receptors remaining at the cell surface, cultures were incubated with goat anti-mouse IgG conjugated to Alexa555 (3 $\mu \mathrm{g} / \mathrm{ml}$, Millipore Bioscience Research Reagents) overnight $(14-16 \mathrm{~h})$ at $4^{\circ} \mathrm{C}$. Cultures were extensively washed with PBS, and cells were permeabilized and nonspecific binding blocked for 30 min using 1\% BSA/PBS containing $0.5 \%$ Triton X-100. To label internalized $\mathrm{GABA}_{\mathrm{A}}$ receptors, cultures were incubated with goat anti-mouse IgG conjugated to Alexa488 $(3 \mu \mathrm{g} / \mathrm{ml}$, Millipore Bioscience Research Reagents) for $60 \mathrm{~min}$ at the room temperature. Cultures were washed extensively and coverslips mounted using Vectashield. Immunoreactivity was visualized as described above using a Zeiss LSM 510 Meta laser scanning confocal microscope.

Determination of $G A B A_{A}$ receptor cell-surface levels using ELISA. Changes in surface and total levels of $\mathrm{GABA}_{\mathrm{A}}$ receptors were analyzed using a cell-surface ELISA assay as described previously (Noel et al., 1999; Bedford et al., 2001; Jovanovic et al., 2004). Striatal neurons were cultured in 24-well plates at a density of $100,000 \mathrm{cells} / \mathrm{cm}^{2}$. Following both short (up to $2 \mathrm{~h}$ ) and long (up to $7 \mathrm{~d}$ ) treatments with vehicle, SKF-38393 $(1 \mathrm{nM})$, or quinpirole $(100 \mathrm{nM})$ as described in the figure legends, cultures were washed with PBS and fixed using $4 \%$ paraformaldehyde/4\% sucrose/PBS for $15 \mathrm{~min}$. The fixative was removed by extensive washing with PBS followed by HBSS (Invitrogen). Nonspecific cell-surface binding of antibody was reduced by incubating cultures for $30 \mathrm{~min}$ in $1 \%$ $\mathrm{BSA} / 10 \%$ rabbit serum/HBSS. In those cultures where total protein levels were evaluated, cells were permeabilized and nonspecific binding blocked by incubating with $0.5 \%$ Triton/ $1 \%$ BSA $/ 10 \%$ rabbit serum/ HBSS for $30 \mathrm{~min}$. Cultures were incubated with anti- $\beta_{2 / 3}$ antibody (1 $\mu \mathrm{g} / \mathrm{ml}$ ) overnight at $4^{\circ} \mathrm{C}$. After extensive washing and nonspecific binding block as described above, cultures were incubated with anti-mouse IgG conjugated to horseradish peroxidase (HRP, 1:2500, Pierce) for 60 min. Cultures were extensively washed and a color substrate 3,3,5,5tetramethylbenzidine (TMB; Sigma-Aldrich) reagent added for $20 \mathrm{~min}$ until sufficient color reaction had developed. Absorbances were read at $\lambda=655 \mathrm{~nm}$ using a spectrophotometer (Duo 800, Beckman Coulter). Controls were routinely used without using primary antibody to determine background levels of peroxidase and nonspecific binding of secondary antibody. Values are expressed as mean \pm SEM (number of experiments, each done in duplicate). Statistical analysis was performed using one-way ANOVA with Dunnett post hoc analysis and two-tailed $t$ test (Graphpad Prism 4.0).

In vitro phosphorylation. Glutathione $S$-transferase (GST) fusion proteins encoding the intracellular transmembrane domain 3-4 loops of $\mathrm{GABA}_{\mathrm{A}}$ receptor $\beta 1-3$ subunits were purified from Escherichia coli as described previously (McDonald and Moss, 1997; Jovanovic et al., 2004).
Table 1. GABA $\mathrm{A}_{\mathrm{A}}$ receptor $\boldsymbol{\beta}$ subunit dephosphorylation by purified protein phosphatases

\begin{tabular}{llll}
\hline & \multicolumn{3}{l}{ Dephosphorylation (\% ${ }^{32}$ P removed) } \\
\cline { 2 - 4 } & PP1C & PP2AC & PP2B \\
\hline$\beta 1$ & $24.8 \pm 6.9$ & $35.9 \pm 1.5$ & $2.1 \pm 1.2$ \\
$\beta 2$ & $15.6 \pm 5.2$ & $31.3 \pm 1.3$ & $3.9 \pm 3.7$ \\
$\beta 3$ & $15.7 \pm 3.9$ & $27.1 \pm 1.1$ & $0.4 \pm 0.2$ \\
Ref. subst. & $23.5 \pm 9.6$ (Phosphoryl. a) & $17.0 \pm 3.6$ (Phosphoryl. a) $33.1 \pm 13.6$ (DARPP32)
\end{tabular}

The activities of purified PP1, PP2A, and calcineurin were measured under initial rate conditions using $1 \mu \mathrm{M}$ ${ }^{32}$ P-labeled $\beta 1-3$ subunits of $\mathrm{GABA}_{\mathrm{A}}$ receptors as described (see Materials and Methods). Relative rates of dephosphorylation were expressed as a percentage of total ${ }^{32} \mathrm{P}$ released in the presence of a phosphatase in $5 \mathrm{~min}$. Phospho- $\beta 1-3$ incubated in the absence of phosphatases served as control. Data represent the mean of three independent experiments done in duplicate.

The catalytic subunit of PKA was purified from bovine heart as described previously (Kaczmarek et al., 1980). Phosphorylation of GST- $\beta 1,-\beta 2$, and $-\beta 3$ used the incubation conditions described for the catalytic subunit of PKA (Huttner et al., 1981), in the presence of $150 \mu \mathrm{M}$ ATP, with trace amounts of $\left[\gamma^{-}{ }^{32} \mathrm{P}\right] \mathrm{ATP}$, to yield a final stoichiometry of $0.4,0.4$, and $1.1 \mathrm{molP} / \mathrm{mol}$ protein, respectively. Incorporation of ${ }^{32} \mathrm{P}$ was determined using measurement of Cerenkov radiation. The phosphorylated proteins were repurified using NICK columns (GE Healthcare). Dopamineand cAMP-regulated phosphoprotein $\left(M_{\mathrm{r}}=32,000\right.$; DARPP-32), phosphorylated by PKA to a stoichiometry of $0.3 \mathrm{molP} / \mathrm{mol}$ of protein (Girault et al., 1989) and phosphorylase a (Cohen et al., 1988), were phosphorylated and repurified as described.

In vitro dephosphorylation. Protein phosphatase 1 catalytic subunit $\left(\mathrm{PP} 1 \mathrm{c}, M_{\mathrm{r}}=37,000\right)$ and protein phosphatase 2A (PP2A, complex of catalytic and regulatory subunit, $M_{\mathrm{r}}=96,000$ ) were purchased (Millipore), and calcineurin $\left(M_{\mathrm{r}}=76,000\right)$ was purified from rat brain (Nairn et al., 1995). Purified phosphatases were assayed in $50 \mathrm{~mm}$ Tris- $\mathrm{HCl}, \mathrm{pH}$ 7.0, $15 \mathrm{~mm}$ 2-mercaptoethanol, and $1 \mathrm{mg} / \mathrm{ml} \mathrm{BSA}$ at $30^{\circ} \mathrm{C}$, as described previously (Desdouits et al., 1998), in the presence of $0.3 \%$ Brij-35 and $0.3 \mathrm{~mm}$ EGTA in the case of PP1c and PP2A, or $100 \mu \mathrm{M} \mathrm{CaCl}_{2}$ and $1 \mu \mathrm{M}$ calmodulin in the case of calcineurin. Reactions were started by the addition of substrate and terminated by the addition of $200 \mu \mathrm{lof} 20 \%(\mathrm{w} / \mathrm{v})$ trichloroacetic acid. After the further addition of $50 \mu \mathrm{l}$ of $10 \mathrm{mg} / \mathrm{ml}$ bovine serum albumin, samples were centrifuged for $5 \mathrm{~min}$ at room temperature at $17,000 \times g$, and the amount of ${ }^{32} \mathrm{P}$ in the supernatant and the pellet was determined by measurement of Cerenkov radiation. PP1c and PP2A activities were measured using $1 \mu \mathrm{M}\left[{ }^{32} \mathrm{P}\right]$ phosphorylase a as substrate (Ingebritsen et al., 1983) under initial rate conditions (the release of phosphate was linear with time and enzyme concentration, and corresponded to $\sim 25 \%$ of the phosphate incorporated into the substrate). For measurements of calcineurin activity, initial rate conditions were determined using $1 \mu \mathrm{M}\left[{ }^{32} \mathrm{P}\right]$ phospho-DARPP-32. Under the same conditions, PP1c-, PP2A-, and calcineurin-mediated dephosphorylation of different $\left[{ }^{32} \mathrm{P}\right]$-labeled phospho-GST- $\beta 1-3$ subunits $(1 \mu \mathrm{M})$ was directly compared to that of standard substrates (phosphorylase a and DARPP-32) (Table 1). Data represent the means of three independent experiments, each done in duplicate. For kinetic analysis, dephosphorylation assays were done using increasing concentrations of phosphosubstrates (GST- $\beta 1$ : $0.6-10 \mu \mathrm{M}$; GST- $\beta 2$ : $0.4-2 \mu \mathrm{M}$; and GST- $\beta 3$ : $0.1-1$ $\mu \mathrm{M})$. The total amount of PP1c and PP2A per reaction was $2.5 \mathrm{ng}$. The $K_{\mathrm{m}}$ and $V_{\max }$ values were calculated from linear regression analysis of Lineweaver-Burk transformations of data describing the initial rates of dephosphorylation as a function of substrate concentration, and represent the means of three independent experiments, each done in duplicate (Table 2).

Treatments with protein kinase and phosphatase inhibitors. For cellsurface ELISA experiments, E17 embryonic striatal cultures (7 DIV) were treated with SKF-38393 (1 nM), quinpirole (100 nM), or dopamine (1 $\mu \mathrm{M})$ for $30 \mathrm{~min}$ with the exception of time course experiments. Those cultures that received treatment with $\mathrm{SCH}-23390(1 \mu \mathrm{M})$, sulpiride $(1 \mu \mathrm{M})$, 8-bromo-cAMP $(10 \mu \mathrm{M})$, forskolin $(10 \mu \mathrm{M})$, fostriecin $(1 \mu \mathrm{M})$, and okadaic acid (100 nM or $1 \mu \mathrm{M}$; all from Tocris Bioscience), calphostin C (200 $\mathrm{nM}$ ), and PD-98059 (50 $\mu \mathrm{M}$, both from Calbiochem), were treated for 10 min before the addition of dopamine receptor agonists; all others were 
Table 2. Kinetic analysis of $\mathrm{GABA}_{A}$ receptor $\beta$ 1-3 subunit dephosphorylation by purified protein phosphatases

\begin{tabular}{|c|c|c|c|c|}
\hline & \multicolumn{2}{|l|}{ PP1 } & \multicolumn{2}{|l|}{ PP2A } \\
\hline & $K_{\mathrm{m}}(\mu \mathrm{M})$ & $\begin{array}{l}V_{\max } \\
(\mathrm{nmolP} / \mathrm{min} / \mathrm{mg})\end{array}$ & $K_{\mathrm{m}}(\mu \mathrm{M})$ & $\begin{array}{l}V_{\max } \\
(\mathrm{nmolP} / \mathrm{min} / \mathrm{mg})\end{array}$ \\
\hline$\beta 1$ & $1.6 \pm 0.9$ & $2.7 \pm 0.5$ & $0.4 \pm 0.1$ & $5.0 \pm 0.5$ \\
\hline$\beta 2$ & $3.8 \pm 2.9$ & $22.2 \pm 15.9$ & $0.8 \pm 0.5$ & $3.2 \pm 0.5$ \\
\hline$\beta 3$ & $0.06 \pm 0.01$ & $2.2 \pm 0.2$ & $0.14 \pm 0.08$ & $2.5 \pm 0.6$ \\
\hline
\end{tabular}

The activities of purified PP1 and PP2A were measured under initial rate conditions for 5 min using various concentrations of ${ }^{22}$-labeled $\beta 1-3$ subunits as described (see Materials and Methods). Phospho- $\beta 1-3$ subunits incubated in the absence of phosphatases served as control. Kinetic parameters were calculated from linear regression of Lineweaver-Burk plots, each representing the mean of three independent experiments, each done in duplicate.

treated with vehicle during this time. Those cultures treated with EGTA (1 mM, Sigma-Aldrich) or BAPTA-AM ( $25 \mu \mathrm{M}$, Calbiochem) received a 30 min treatment before dopamine receptor agonists; all others received vehicle during this time.

Immunoblotting. E17 embryonic striatal cultures (7 DIV) were treated with SKF-38393 (1 nM), quinpirole (100 nM), or both for 5 min to $2 \mathrm{~h}$. Those cultures that received treatment with PD-98059 (50 $\mu \mathrm{M})$, fostriecin $(1 \mu \mathrm{M})$, or okadaic acid $(1 \mu \mathrm{M})$ were treated for $10 \mathrm{~min}$ before the addition of dopamine receptor agonists for $10 \mathrm{~min}$; all others were treated with vehicle during this time. Samples were lysed with $1 \%$ SDS and protein concentration determined using BCA assay. Samples with the same amount of total protein were separated using SDS-PAGE and transferred onto a nitrocellulose membrane. Nonspecific binding was blocked by incubation of membranes with TBS/Tween buffer containing 2 $\mathrm{mg} / \mathrm{ml}$ BSA. Membranes were incubated with rabbit anti-phospho- $\beta$ subunit antibody purified against a phospho-Ser409-peptide column (Jovanovic et al., 2004) or rabbit total $\beta 3$ antibody $(0.5 \mu \mathrm{g} / \mathrm{ml}$, Phosphosolutions, Aurora, CO), for $90 \mathrm{~min}$, followed by washing with TBS/Tween. Membranes incubated with the total $\beta 3$ antibody were blocked using TBS/ Tween buffer containing 1.5\% (w/v) powdered milk. Membranes were incubated with $\left[{ }^{125} \mathrm{I}\right]$-anti-rabbit polyclonal antibody (GE Healthcare) for 60 min, and washed as before using TBS/Tween buffer. Detection of immunoreactivity was performed using a phosphoimager (Molecular Devices).

\section{Results \\ Dopaminergic projections and dopamine receptors are present in the embryonic E17 striatum}

In the ontogeny of the rat, dopaminergic fibers positive for tyrosine hydroxylase $(\mathrm{TH})$ arrive in the striatal enlarge on E14 (Specht et al., 1981; Voorn et al., 1988). To establish the presence of dopaminergic system in the embryonic rat (E17) striatum in vivo, whole-brain sections cut through the midbrain-hindbrain region were stained using antibodies specific for $\mathrm{TH}, \mathrm{D}_{1} \mathrm{R}$, and $\mathrm{D}_{2} \mathrm{R}$. Prominent TH fibers and terminal-like staining were detected at this stage of development (Fig. 1A). The expression of dopamine $\mathrm{D}_{1} \mathrm{R}$ and $\mathrm{D}_{2} \mathrm{R}$, and a high degree of colocalization between these receptors, was also observed throughout the embryonic striatum (Fig. $1 B$ ). The levels of tissue dopamine were measured in acutely prepared homogenates using HPLC, revealing $11.4 \pm 0.5 \mathrm{nmol}$ of dopamine per milligram of total protein in E17 and $14.4 \pm 0.6 \mathrm{nmol}$ of dopamine per milligram of total protein in E18 striatal tissue. In contrast, levels of tissue noradrenaline and 5-HT were below detection in these experiments.

\section{Dopamine receptor activation decreases the number of GABAergic synapses and the size of $\mathrm{GABA}_{\mathrm{A}}$ receptor clusters} Embryonic striatal neurons in vitro form a highly homogenous population of precursors of GABAergic medium spiny neurons that display a number of properties that are similar to their in vivo counterparts; they form functional GABAergic synapses, express $\mathrm{D}_{1} \mathrm{Rs}$ and $\mathrm{D}_{2} \mathrm{Rs}$, and display similar electrophysiological properties (Bockaert et al., 1986; Aizman et al., 2000; Falk et al., 2006).
The coexpression of $\mathrm{D}_{1} \mathrm{R}$ and $\mathrm{D}_{2} \mathrm{R}$ demonstrated in vivo (Fig. $1 \mathrm{~B}$ ) was also detected in vitro, where all the neurons imaged showed a strong immunoreactivity for both receptors at 7 DIV (Fig. 2A) and 14 DIV (Fig. $2 B$ ). To examine whether dopamine regulates the extent of synaptic connectivity between these neurons, we used confocal microscopy to analyze the number of GABAergic synapses upon the application of SKF-38393, a $\mathrm{D}_{1} \mathrm{R}$-specific agonist, or quinpirole, a $\mathrm{D}_{2} \mathrm{R}$-specific agonist. Localization of VIAAT-1, a presynaptic marker of GABAergic and glycinergic synapses (Dumoulin et al., 1999) was found to completely overlap with that of GAD-65, a presynaptic marker specific for GABAergic synapses (data not shown). As these presynaptic markers colocalize with surface-expressed $\mathrm{GABA}_{\mathrm{A}}$ receptor $\beta_{2 / 3}$ subunit clusters, reflecting the close apposition between the presynaptic and postsynaptic components of GABAergic synapses (Chih et al., 2005; Dong et al., 2007; Yu et al., 2007), we estimated the number of these synapses along defined length of primary neuronal processes.

Upon treatment with SKF-38393 (1 nM) or quinpirole (100 nM) for $72 \mathrm{~h}$ or $7 \mathrm{~d}$, we observed a significant decrease in the colocalization between $\mathrm{GABA}_{\mathrm{A}}$ receptor $\beta_{2 / 3}$ subunit clusters expressed at the cell-surface and VIAAT-1-positive presynaptic terminals: $79.6 \pm 3.0 \%$ of surface $\beta_{2 / 3}$ subunit clusters, which were colocalized with VIAAT-1 puncta in control cultures (7 DIV), was significantly decreased to $50.1 \pm 3.7 \%(p<0.01$, paired $t$ test, $n=26)$ by $72 \mathrm{~h}$ treatment with SKF-38393, or to $49.8 \pm 3.6 \%$ $(p<0.01$, paired $t$ test, $n=21)$ by $72 \mathrm{~h}$ treatment with quinpirole (Fig. 2C,E). Similarly, a prolonged $7 \mathrm{~d}$ treatment of cells (from 7 to 14 DIV) with either of the agonists resulted in a significant decrease in colocalization between $\beta_{2 / 3}$ subunit clusters and VIAAT-1-positive presynaptic terminals: $90.6 \pm 1.2 \%$ colocalization observed in control vehicle-treated cells was significantly reduced to $68.0 \pm 2.4 \%(p<0.01$, paired $t$ test, $n=24)$ by SKF-38393, and to $70.0 \pm 3.0 \%(p<0.01$, paired $t$ test, $n=21)$ by quinpirole (Fig. $2 D, F$ ). Thus, both $\mathrm{D}_{1}$ Rs and $\mathrm{D}_{2}$ Rs decrease the number of GABAergic synapses formed between embryonic precursors of medium spiny neurons in vitro.

The observed reduction in the number of GABAergic synapses may occur due to a reduction in the number of presynaptic GABAergic terminals or postsynaptic $\mathrm{GABA}_{\mathrm{A}}$ receptor clusters, or inhibition of the formation and maintenance of synaptic contacts. Alternatively, these changes may result from changes in the structure of presynaptic or postsynaptic elements. To evaluate these possibilities, we performed detailed quantitative analysis of the area and the number of $\beta_{2 / 3}$ puncta and VIAAT- 1 puncta along the initial $20 \mu \mathrm{m}$ of primary neuronal processes following dopamine receptor activation.

Our analysis revealed a significant decrease in the area of surface $\beta_{2 / 3}$-positive puncta following dopamine receptor activation. In control cells cultured for 7 DIV, the area of $\beta_{2 / 3}$ subunit puncta was $0.45 \pm 0.04 \mu \mathrm{m}^{2}$, which was significantly decreased to $0.29 \pm 0.02 \mu \mathrm{m}^{2}$ ( $p<0.001$, paired $t$ test, $\left.n=26\right)$, or to $0.31 \pm$ $0.03 \mu \mathrm{m}^{2}(p<0.001$, paired $t$ test, $n=21)$ by $72 \mathrm{~h}$ treatment with SKF-38393 or quinpirole, respectively (Fig. 2G,I, 72 h). Dopamine receptor activation produced similar effects in cells cultured for 14 DIV: in control cells, the area of $\beta_{2 / 3}$ subunit puncta was $0.67 \pm 0.04 \mu \mathrm{m}^{2}$ compared to $0.46 \pm 0.03 \mu \mathrm{m}^{2}$ after SKF-38393 treatment $(p<0.001$, paired $t$ test, $n=24)$ for $7 \mathrm{~d}$ and $0.48 \pm$ $0.03 \mu \mathrm{m}^{2}$ after $7 \mathrm{~d}$ treatment with quinpirole $(p<0.001$, paired $t$ test, $n=21$ ) (Fig. $2 H, I, 7$ d). However, we observed no significant change in the number of $\beta_{2 / 3}$ puncta at the cell surface following activation of either $D_{1}$ Rs or $D_{2} R s$ for $72 \mathrm{~h}$ or $7 \mathrm{~d}$. In control cells cultured for 7 DIV, there were $5.31 \pm 0.31 \beta_{2 / 3}$ subunit puncta compared to $5.59 \pm 0.29$ in those treated with 
A

TH (x5)

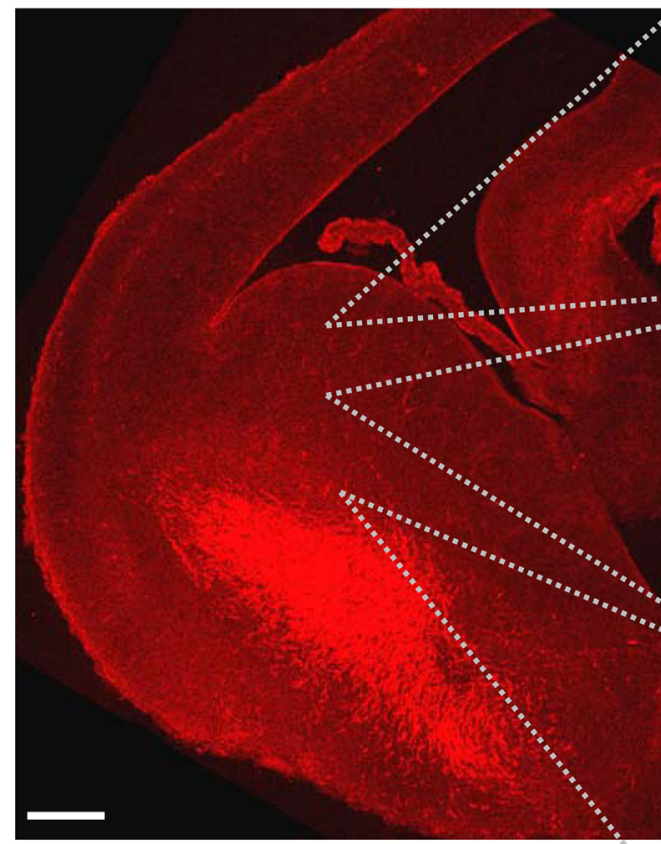

B

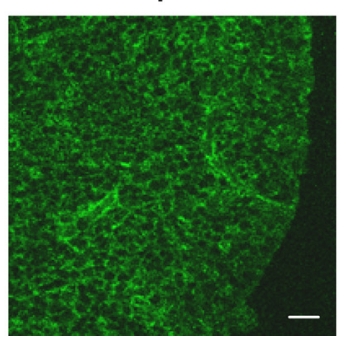

$D_{2} R$

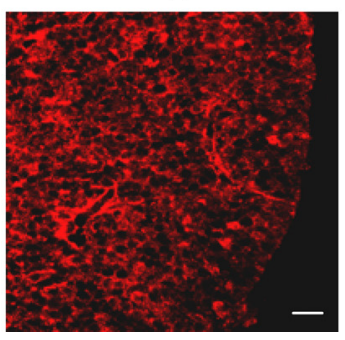

TH (x63)
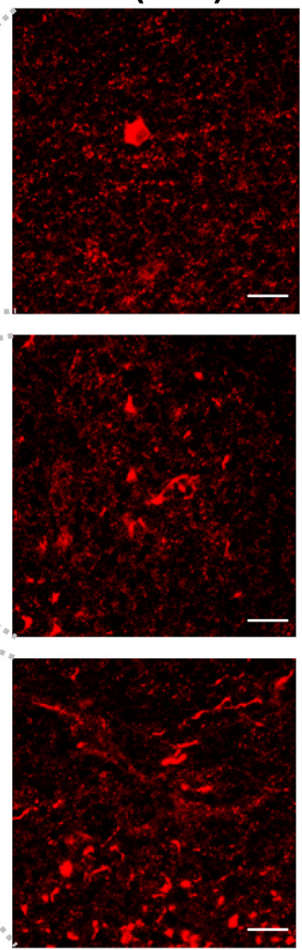

ventral

merge

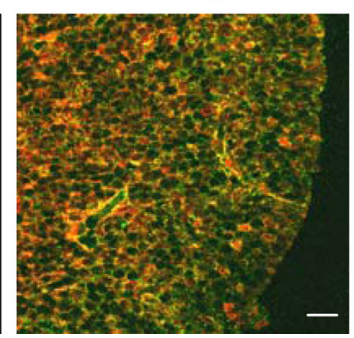

Figure 1. Dopaminergic projections and dopamine receptors are present in the embryonic striatum. $\boldsymbol{A}$, Dopaminergic projec tions positive for TH $(\times 5$, scale bar corresponds to $200 \mu \mathrm{m})$ form a prominent network of fibers in the ventral part of the striatal enlargement, while terminal-like staining $(\times 63$, scale bars correspond to $20 \mu \mathrm{m})$ is abundant in the dorsal part of the embryonic (E17) striatum. $B$, Dopamine $D_{1}$ receptors and $D_{2}$ receptors are expressed throughout the whole striatal enlargement and show a high-degree of colocalization ( $\times 63$, scale bars correspond to $20 \mu \mathrm{m}$ ).

SKF-38393 $(p>0.05$, paired $t$ test, $n=26)$ and $5.36 \pm 0.26$ in those treated with quinpirole for $72 \mathrm{~h}(p>0.05$, paired $t$ test, $n=$ 21) (Fig. $2 K, 72 \mathrm{~h}$ ). The number of $\beta_{2 / 3}$ subunit puncta in neurons cultured for 14 DIV was $7.25 \pm 0.28$ in control cells and $7.43 \pm 0.30$ in those treated with SKF-38393 for $7 \mathrm{~d}(p>0.05$, paired $t$ test, $n=24)$ and $7.83 \pm 0.41$ in those treated with quinpirole for $7 \mathrm{~d}$ ( $p>0.05$, paired $t$ test, $n=21$ ) (Fig. $2 K, 7 \mathrm{~d}$ ).

To assess changes in presynaptic GABAergic terminals, we analyzed the area and the number of VIAAT-1-positive puncta. There was no significant change in the area of VIAAT-1 puncta following $72 \mathrm{~h}$ treatment with SKF-38393 or quinpirole: the average area of puncta in vehicle-treated cells was $0.49 \pm 0.03 \mu \mathrm{m}^{2}$ in comparison with $0.45 \pm 0.06 \mu \mathrm{m}^{2}$ in SKF-38393-treated $(p>0.05$, paired $t$ test, $n=26$ ) or $0.49 \pm 0.05 \mu \mathrm{m}^{2}$ in quinpirole-treated ( $p>0.05$, paired $t$ test, $n=21$ ) cultures (Fig. 2G,J, $72 \mathrm{~h}$ ). Similar results were obtained in cultures treated for $7 \mathrm{~d}$ with SKF-38393 or quinpirole: the average area of puncta in vehicle-treated cells was $0.56 \pm 0.03 \mu \mathrm{m}^{2}$ in comparison with $0.55 \pm 0.03 \mu \mathrm{m}^{2}$ in SKF-38393-treated $(p>0.05$, paired $t$ test, $n=24)$ or $0.57 \pm 0.04 \mu \mathrm{m}^{2}$ in quinpirole-treated
( $p>0.05$, paired $t$ test, $n=24$ ) cultures (Fig. $2 H, J, 7 \mathrm{~d}$ ). The number of VIAATpositive puncta also remained unchanged during $72 \mathrm{~h}$ treatment with SKF-38393 or quinpirole: vehicle-treated cells had $5.33 \pm 0.30$ puncta compared to $5.20 \pm$ 0.30 in SKF-treated $(p>0.05$, paired $t$ test, $n=24)$ and $5.31 \pm 0.29$ in quinpirole-treated ( $p>0.05$, paired $t$ test, $n=21$ ) cultures (Fig. $2 L, 72 \mathrm{~h}$ ). Similarly, the number of VIAAT-positive puncta in controls $(6.47 \pm 0.19, p>0.05$, paired $t$ test, $n=24$ ) remained unchanged during $7 \mathrm{~d}$ treatment with SKF-38393 $(6.57 \pm 0.30, p>0.05$, paired $t$ test, $n=$ $24)$ or quinpirole $(6.49 \pm 0.30, p>0.05$, paired $t$ test, $n=24$ ) (Fig. $2 L, 7 \mathrm{~d}$ ).

To assess whether the observed dopamine receptor-mediated changes in morphology correlated with changes in the number of functional GABAergic synapses, we used confocal microscopy to analyze the degree of colocalization between GABAergic terminals labeled by activity-dependent uptake of aldehyde-fixable styryl dye FM143FX (Sara et al., 2002), and $\mathrm{GABA}_{\mathrm{A}}$ receptor $\beta_{2 / 3}$ subunit clusters. We demonstrate that colocalization between surface $\beta_{2 / 3^{-}}$ and FM1-43FX-positive puncta was significantly decreased from $68.1 \pm 2.6 \%$ in control conditions to $42.3 \pm 3.1 \%(p<$ 0.01 , paired $t$ test, $n=26$ ) following $72 \mathrm{~h}$ treatment with SKF-38393, and to $45.6 \pm$ $3.2 \%(p<0.01$, paired $t$ test, $n=21)$ following treatment with quinpirole (Fig. $3 A, B)$. Prolonged $7 \mathrm{~d}$ treatment of cells (from 7 to 14 DIV) with either of agonists also resulted in a significant decrease in colocalization between surface $\beta_{2 / 3^{-}}$and FM1-43FX-positive puncta: $75.9 \pm 1.8 \%$ observed in control conditions was significantly decreased to $36.6 \pm 2.4 \%(p<0.01$, paired $t$ test, $n=24)$ upon the treatment with SKF-38393, and to $35.8 \pm 2.6 \%(p<0.01$, paired $t$ test, $n=21$ ) upon the treatment with quinpirole (Fig. $3 C$ ).

We performed whole-cell patch-clamp analysis of striatal neurons to measure spontaneous activity at inhibitory synapses (mIP$\mathrm{SPs}$ ) in response to application of dopamine receptor agonists. We demonstrate that cultured embryonic striatal neurons exhibit mIPSPs with an amplitude of $1.8 \pm 0.2 \mathrm{mV}$ and a frequency of $2.3 \pm 0.2$ $\mathrm{Hz}(n=6)($ Fig. 3D-F). These spontaneous currents were GABAergic since they were completely eliminated by the addition of picrotoxin $(50 \mu \mathrm{M})$ to the perfusion bath (Fig. 3D, left, + picrotoxin). Following $72 \mathrm{~h}$ treatment with SKF-38393, the amplitudes and frequency of mIPSPs were significantly decreased compared to control: amplitudes of mIPSPs were $0.9 \pm 0.3 \mathrm{mV}$, and frequency was $1.4 \pm$ $0.2 \mathrm{~Hz}(p<0.05$, two-tailed $t$ test, $n=4)$ (Fig. $3 D-F)$. The remaining spontaneous currents in SKF-38393-treated cultures were also completely inhibited by picrotoxin (Fig. $3 D$, right, + picrotoxin). The amplitudes and frequency of mIPSPs were also reduced in cultures treated for $72 \mathrm{~h}$ with quinpirole (Fig. $3 E, F$ ). However, short treatments (up to $30 \mathrm{~min}$ ) with SKF also reduced the amplitude and frequency of mIPSPs in these cultures from $2.0 \pm 1.0 \mathrm{mV}$ and $3.0 \pm$ 
A

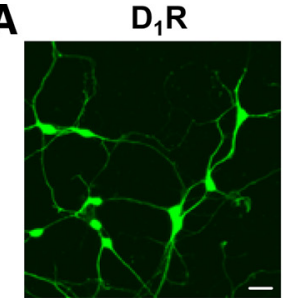

C

$\mathrm{GABA}_{A} \beta_{2 / 3}$
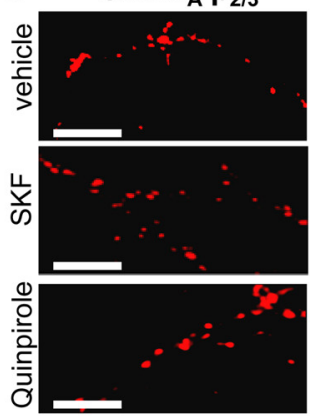

E

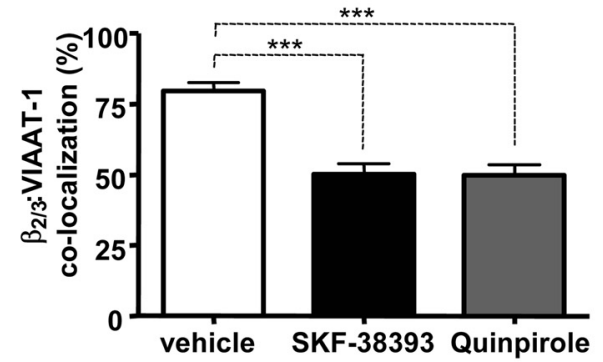

G
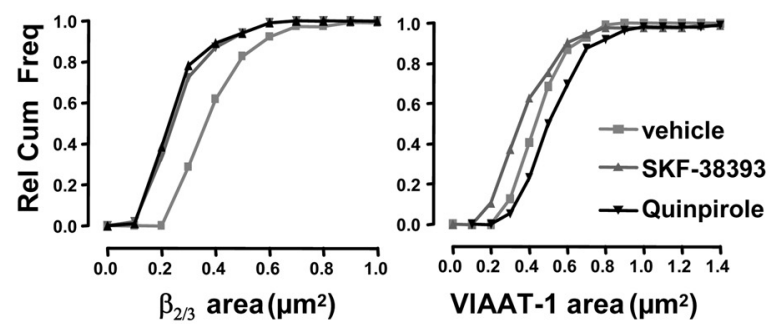

I

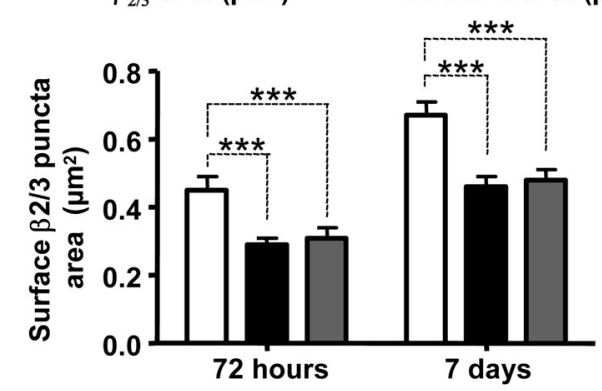

K

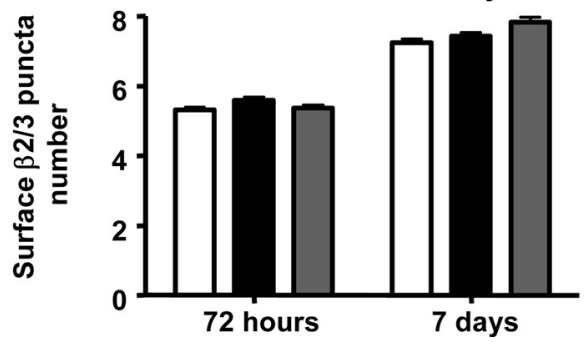

merge

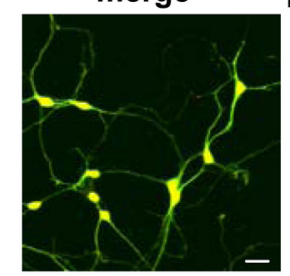

merge

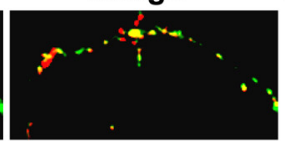

D $\quad \mathrm{GABA}_{\mathrm{A}} \beta_{2 / 3}$
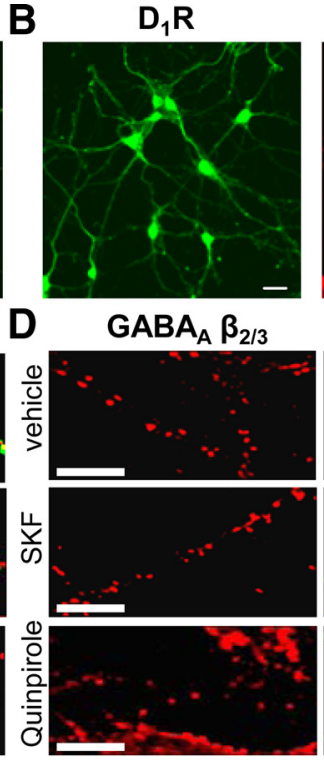

$D_{2} R$

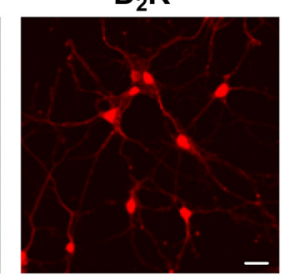

VIAAT-1
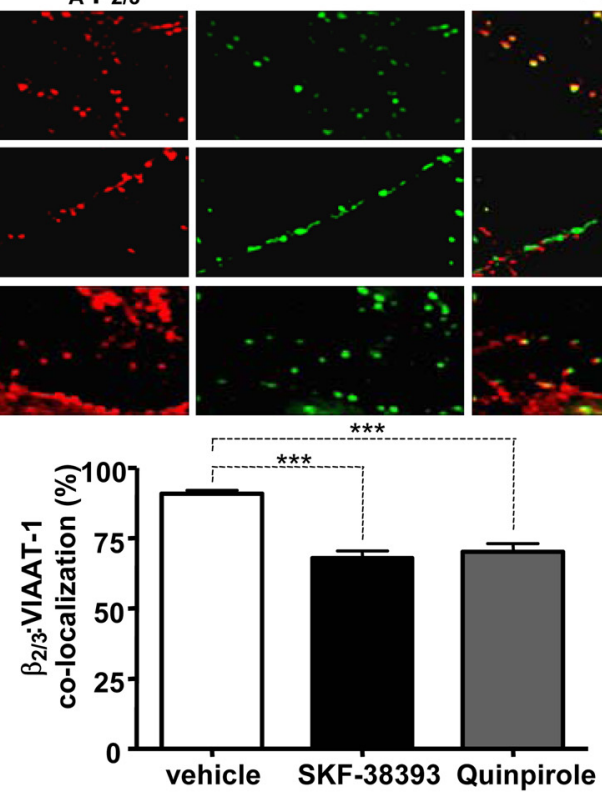

H

$\mathbf{F}$
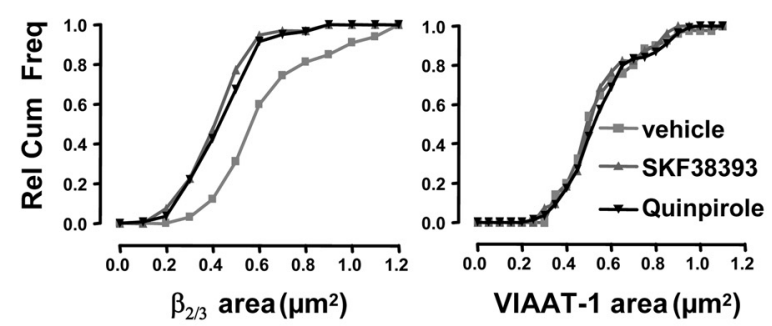

J
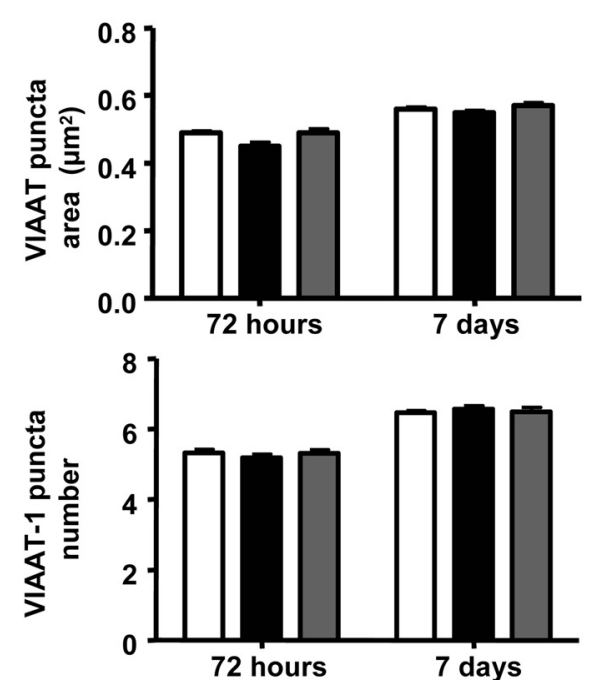

Figure 2. Dopamine receptor activation decreases the colocalization of postsynaptic $G A B A_{A}$ receptor $\beta_{2 / 3}$ subunit puncta with presynaptic VIAAT- 1 puncta. Embryonic striatal neurons express both $\mathrm{D}_{1}$ Rs and $\mathrm{D}_{2}$ Rs when cultured for $7 \mathrm{~d}(7 \mathrm{DIV})(\boldsymbol{A})$, and $14 \mathrm{~d}(14 \mathrm{DIV})(\boldsymbol{B})$. Scale bars correspond to $20 \mu \mathrm{m}$. Striatal cultures were treated for $72 \mathrm{~h}$ (from 4 to $\left.7 \mathrm{DIV}\right)(\boldsymbol{C})$ or $7 \mathrm{~d}$ (from 7 to $\left.14 \mathrm{DIV}\right)$ (D) with vehicle, SKF-38393, or quinpirole, and stained for GABA $\mathrm{R} \beta_{2 / 3}$ subunit (in red) and VIAAT-1 (in green). Scale bars correspond to $10 \mu \mathrm{m}$. The percentage of $\beta_{2 / 3}$ subunit-positive puncta that colocalized with VIAAT-1 puncta was significantly decreased in cultures treated with SKF-38393 or quinpirole for $72 \mathrm{~h}(\boldsymbol{E})$ or $7 \mathrm{~d}(\boldsymbol{F}) . \boldsymbol{G}, \boldsymbol{H}$, Relative cumulative frequency plots of $\beta_{2 / 3}$-immunoreactive puncta and VIAAT-1-positive puncta (in square micrometers) measured along a defined length of primary processes $(20 \mu \mathrm{m})$ following the treatment with vehicle (Figure legend continues.) 

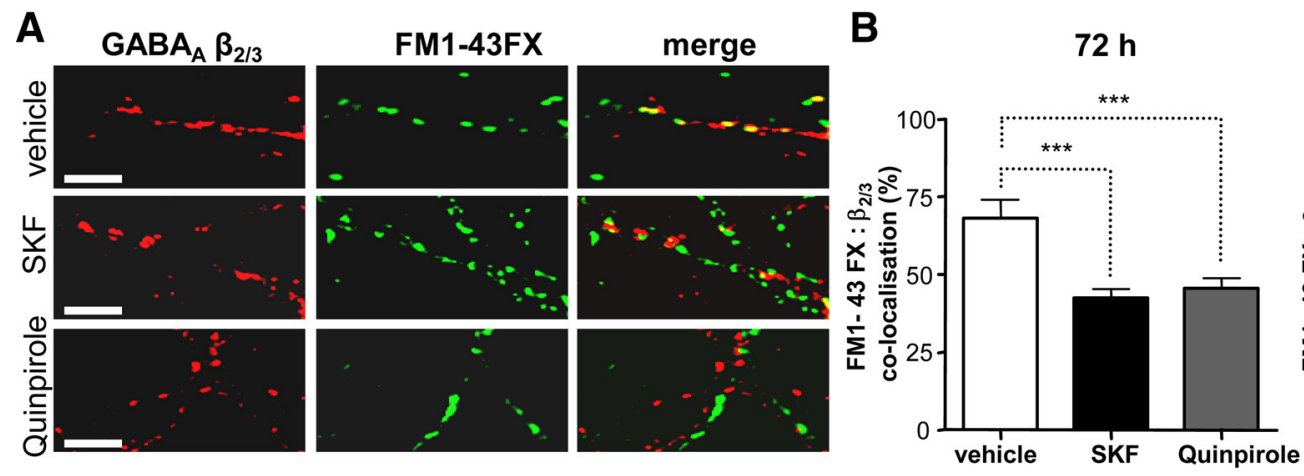

D

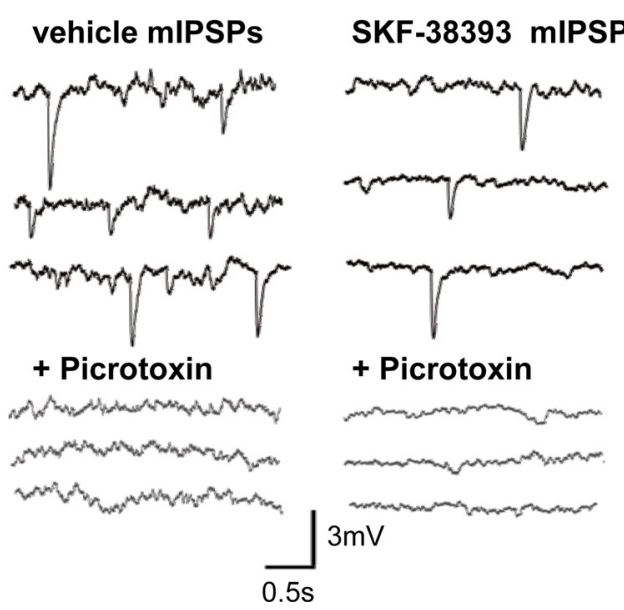

B

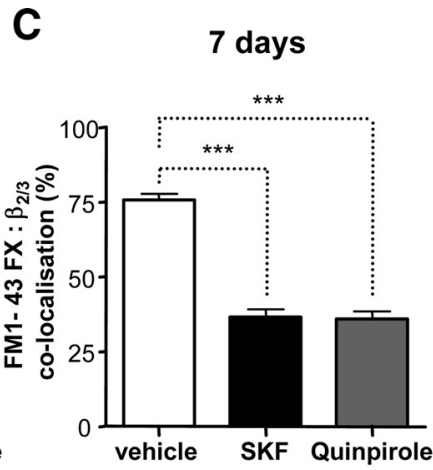

E

$\mathbf{F}$

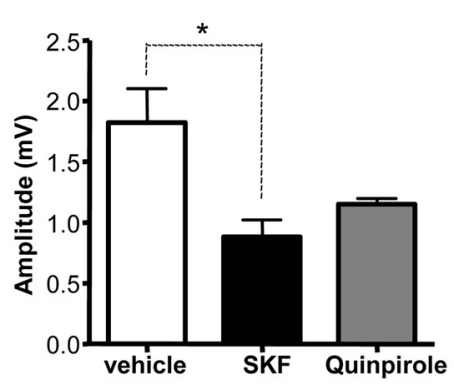

Figure 3. Dopamine receptor activation decreases the number of functional GABAergic synapses. $A$, Cultures were treated for $72 \mathrm{~h}$ (from 4 to 7 DIV) with vehicle, SKF-38393, or quinpirole, followed by activity-dependent labeling with FM1-43FX. Scale bars correspond to $10 \mu \mathrm{m}$. SKF-38393 and quinpirole significantly decreased the colocalization of $\beta_{2 / 3}$ puncta (in red) and FM1-43FX puncta (in green) after treatment for $72 \mathrm{~h}$ (from 4 to $7 \mathrm{DIV}, \boldsymbol{B}$ ), or $7 \mathrm{~d}$ (from 7 to $14 \mathrm{DIV}, \boldsymbol{C}$ ). Bars represent mean \pm SEM. Statistics was performed using $t$ test: ${ }^{* * *} p<0.001$. D, mIPSPs recorded in striatal neurons after $72 \mathrm{~h}$ treatment (from 4 to 7 DIV) with vehicle (control) or SKF-38393 in the presence of TTX ( $1 \mu \mathrm{M}$ ), D-AP5 (50 mM), and CNQX (20 mM), before and after bath application of GABA receptor antagonist picrotoxin $(50 \mu \mathrm{M},+$ picrotoxin). Three representative traces for each condition are shown. Scale refers to all four conditions. $\boldsymbol{E}$, $\boldsymbol{F}$, SKF-38393 and quinpirole treatments decreased the amplitude $(\boldsymbol{E})$ and frequency $(\boldsymbol{F})$ of mIPSPs. Bars represent mean \pm SD. Statistical analysis was performed using two-tailed $t$ test: ${ }^{*} p<0.05$.

$0.8 \mathrm{~Hz}$, respectively, in vehicle-treated cultures, to $0.9 \pm 0.7 \mathrm{mV}$ and $0.6 \pm 0.4 \mathrm{~Hz}(p<0.05$, two-tailed $t$ test, $n=4$, data not shown $)$. Similar effects were observed following short treatments with quinpirole: amplitudes and frequencies of mIPSPs were reduced from $3.2 \pm$ $0.4 \mathrm{mV}$ and $3.2 \pm 0.8 \mathrm{~Hz}$ in vehicle-treated cultures to $1.6 \pm 0.3 \mathrm{mV}$ and $1.3 \pm 0.3 \mathrm{~Hz}$, respectively $(p<0.05$, two-tailed $t$ test, $n=3$, data not shown). These data provide further evidence that both $D_{1}$ Rs and $D_{2} R s$ decrease the number of functional GABAergic synapses formed between embryonic precursors of medium spiny neurons.

\section{Dopamine receptors decrease cell-surface expression of $\mathrm{GABA}_{\mathrm{A}}$ receptors}

The reduction in size of $\mathrm{GABA}_{\mathrm{A}}$ receptor $\beta_{2 / 3}$ subunit-positive clusters at the cell surface observed upon activation of $D_{1}$ Rs and

\section{$\leftarrow$}

(Figure legend continued.) (white), SKF-38393 (black), or quinpirole (dark gray) for $72 \mathrm{~h} \mathrm{(4-7}$ DIV, left) (G) or $7 \mathrm{~d}$ (7-14 DIV, right) (H). I, SKF-38393 (black) and quinpirole (gray) significantly decreased the average $\beta_{2 / 3}$ subunit punctum area in comparison with controls (vehicle treated, white) cells, following treatments for $72 \mathrm{~h}$ or $7 \mathrm{~d}$. J, SKF-38393 (black) and quinpirole (gray) had no effect on the average VIAAT-1 punctum area in comparison with controls (vehicle treated, white), following treatments for $72 \mathrm{~h}$ or $7 \mathrm{~d}$. $\boldsymbol{K}$, The total number of $\beta_{2 / 3}$-positive puncta remained unchanged following the treatment with vehicle (white), SKF-38393 (black), or quinpirole (gray) for $72 \mathrm{~h}$ or $7 \mathrm{~d}$. $L$, The total number of VIAAT-1-positive puncta remained unchanged following the treatment with vehicle (white), SKF-38393 (black), or quinpirole (gray) for $72 \mathrm{~h}$ or $7 \mathrm{~d}$. Bars represent mean \pm SEM. Statistical analysis was performed using paired $t$ test: ${ }^{* * *} p<0.001$.
$\mathrm{D}_{2} \mathrm{Rs}$ may be occurring due to increased lateral diffusion from synaptically clustered receptor pools to more diffuse extrasynaptic pools (Thomas et al., 2005), without an overall decrease in the total surface numbers. Alternatively, it may reflect an overall reduction in their number at the cell surface, without changing a balance between clustered and diffuse receptors. To distinguish between these two mechanisms, we measured the cell-surface levels of $\mathrm{GABA}_{\mathrm{A}}$ receptor $\beta_{2 / 3}$ subunits using cell-surface ELISA assays (Noel et al., 1999; Bedford et al., 2001; Jovanovic et al., 2004).

We demonstrate that $D_{1} R$ activation by SKF-38393 led to a significant and prolonged decrease in the surface expression of $\mathrm{GABA}_{\mathrm{A}}$ receptors, which was observed as early as $10 \mathrm{~min}$ upon the application of the drug and maintained for up to $7 \mathrm{~d}$ in the continuous presence of the drug (one-way ANOVA; with Dunnett post hoc analysis; $n=4$ ) (Fig. $4 A$, in black): surface $\beta_{2 / 3}$ subunit levels were reduced to $82.4 \pm 6.2 \%$ of vehicle $(p<0.05)$ after $10 \mathrm{~min}$, to $81.3 \pm 3.5 \%$ of vehicle $(p<0.05)$ after $30 \mathrm{~min}$; to $82.9 \pm 5.6 \%(p<0.05)$ of vehicle after $60 \mathrm{~min}$; to $80.4 \pm 5.9 \%$ $(p<0.05)$ of vehicle after $120 \mathrm{~min}$; to $82.4 \pm 3.1 \%$ of vehicle $(p<0.01)$ after $72 \mathrm{~h}$, and to $80.8 \pm 5.2 \%$ of vehicle $(p<0.05)$ after 7 -d-long treatment with SKF-38393. $\mathrm{D}_{1} \mathrm{R}$ activation had no significant effect on the total levels of $\beta_{2 / 3}$ subunits at any of those time points tested (Fig. 4A, in gray). The effects of SKF-38393 $(88.1 \pm 1.9 \%$ of vehicle-treated controls) were blocked by the application of $\mathrm{D}_{1} \mathrm{R}$ antagonist SCH-23390 (101.3 $\pm 4.8 \%$ of vehicletreated control, $p<0.05$, paired $t$ test, $n=6$ ) (Fig. 4C). 
We also examined the effects of $\mathrm{D}_{2} \mathrm{R}$ activation by quinpirole on $\mathrm{GABA}_{\mathrm{A}}$ receptor surface levels using cell-surface ELISA approach. Quinpirole decreased the surface expression of $\beta_{2 / 3}$ subunits to $94.0 \pm 1.1 \%$ following $10 \mathrm{~min}$ treatment $(p>0.05)$; to $83.8 \pm 2.0 \%$ after $30 \mathrm{~min}$ treatment $(p<$ $0.01)$, to $91.6 \pm 2.0 \%$ after 60 min treatment ( $p>0.05)$; to $84.1 \pm 7.2 \%$ after 120 min treatment $(p<0.01)$, to $85.4 \pm 3.2 \%$ after $72 \mathrm{~h}$ treatment $(p<0.05)$; and to $86.5 \pm 3.7 \%$ after $7 \mathrm{~d}$ treatment $(p<0.05$, one-way ANOVA with Dunnett post hoc analysis; $n=4$ ) (Fig. $4 B$, in black). $\mathrm{D}_{2} \mathrm{R}$ activation had no significant effect on the total levels of $\beta_{2 / 3}$ subunits at any of time points tested (Fig. $4 B$, in gray). The decrease observed after $30 \mathrm{~min}$ treatment with quinpirole $(74.0 \pm 6.3 \%$ of control) was prevented by the $\mathrm{D}_{2} \mathrm{R}$ antagonist sulpiride $(93.9 \pm 2.9 \%$ of control, $p<0.05$, paired $t$ test, $n=4)$ (Fig. $4 D$ ).

Furthermore, we demonstrate that the application of dopamine $(1 \mu \mathrm{M})$ also caused a prominent reduction in the cell-surface expression of $\mathrm{GABA}_{\mathrm{A}}$ receptors via activation of both $\mathrm{D}_{1}$ Rs and $\mathrm{D}_{2}$ Rs. Significantly, the decrease in surface $\beta_{2 / 3}$ subunit levels to $75.6 \pm 2.3 \%$ of vehicle-treated controls was partially attenuated to $86.7 \pm 4.3 \%$ of vehicle-treated controls in the presence of $\mathrm{D}_{1} \mathrm{R}$ antagonist SCH-23390 $(1 \mu \mathrm{M})$, and to $84.7 \pm 3.9 \%$ of vehicle-treated controls in the presence of $\mathrm{D}_{2} \mathrm{R}$ antagonist sulpiride (10 $\mu \mathrm{M}, p<0.05$, one-way ANOVA with Dunnett post hoc analysis; $n=5$ ) (Fig. 4E).

Although both $\mathrm{D}_{1}$ Rs and $\mathrm{D}_{2}$ Rs appear to mediate regulation of $\mathrm{GABA}_{\mathrm{A}}$ receptor cell-surface levels by dopamine, application of specific receptor agonists SKF-38393 (1 $\mathrm{nM})$ and quinpirole $(100 \mathrm{nM})$ at the same time resulted in a reduction in surface $\beta_{2 / 3}$ subunit levels to $71.4 \pm 7.7 \%$ of vehicle-

treated controls, which was slightly but not significantly more pronounced than the application of SKF-38393 (81.3 $\pm 3.5 \%$ of vehicletreated control $)$ or quinpirole alone $(83.8 \pm 2.0 \%$ of vehicle-treated control, $p<0.05$, one-way ANOVA with Dunnett post hoc analysis; $n=4)($ Fig. $4 F)$. Thus, both $\mathrm{D}_{1} \mathrm{R}$ and $\mathrm{D}_{2} \mathrm{R}$ activation leads to a significant and prolonged decrease in cell-surface levels of $\mathrm{GABA}_{\mathrm{A}}$ receptors in embryonic striatal neurons.

\section{Dopamine receptor activation enhances $\mathrm{GABA}_{\mathrm{A}}$ receptor endocytosis}

$\mathrm{GABA}_{\mathrm{A}}$ receptors are continuously internalized by clathrindependent endocytosis and replaced by insertion of newly synthesized receptors (Kittler et al., 2000). To examine whether dopamine receptor activation leads to an increase in $\mathrm{GABA}_{\mathrm{A}}$ receptor endocytosis, we visualized this process using immunocytochemistry (van Rijnsoever et al., 2005). Cultured striatal neurons were incubated with the same anti- $\beta_{2 / 3}$ subunit antibody as in cell-surface ELISA experiments to label $\mathrm{GABA}_{\mathrm{A}}$ receptors at the cell surface. Cultures were subsequently treated with vehicle, SKF-38393 (1 nM), or quinpirole $(100 \mathrm{~nm})$ for $30 \mathrm{~min}$. Following fixation, $\mathrm{GABA}_{\mathrm{A}}$ receptors remaining at the cell surface were probed with a secondary antibody

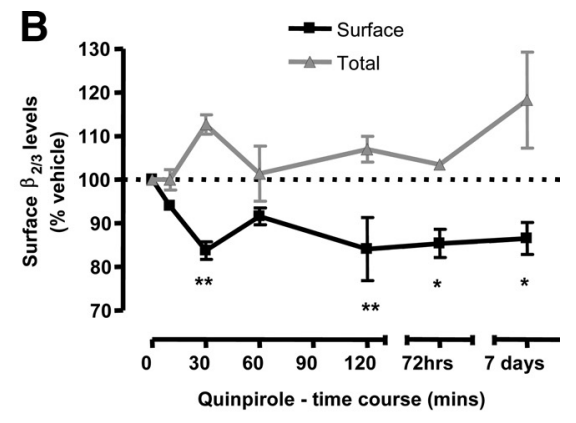

D

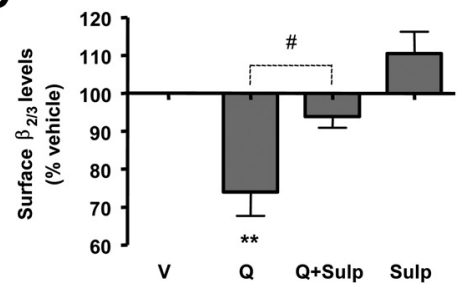

$\mathbf{F}$

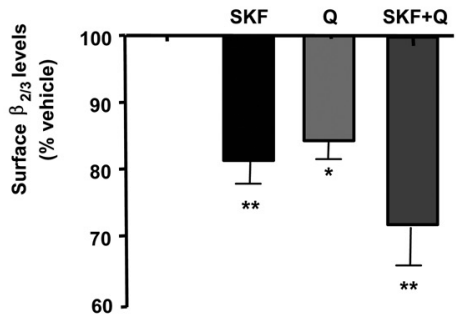

Figure 4. Activation of dopamine receptors decreases the cell-surface expression of GABA receptors. $\boldsymbol{A}$, SKF-38393 (1 nm) caused a significant and prolonged decrease in the level of $\beta_{2 / 3}$ subunits (black) expressed at the cell surface, but not in total levels

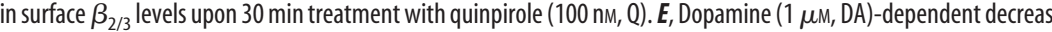
alone. Bars represent mean \pm SEM. Statistical analysis was performed using one-way ANOVA with either a Dunnett post hoc analysis versus control $\left({ }^{*} p<0.05 ;{ }^{* *} p<0.01\right)$, or paired $t$ test $\left({ }^{\#} p<0.05\right)$.

conjugated to Alexa555 (Fig. 5A, $B$, in red). Following permeabilization, the internalized receptors were probed with a secondary antibody conjugated to Alexa488 (Fig. $5 A, B$, in green). The two pools were analyzed using confocal microscopy. We demonstrate that both treatments increased the amount of internalized $\mathrm{GABA}_{\mathrm{A}}$ receptors with a concomitant reduction in those located at the cell surface relative to vehicle-treated controls (Fig. $5 A, B$ ). A small amount of internalized $\beta_{2 / 3}$ subunits observed in neurons treated with vehicle is likely to be due to the constitutive internalization of $\mathrm{GABA}_{\mathrm{A}}$ receptors (van Rijnsoever et al., 2005).

To investigate these processes further, we performed cellsurface ELISA assays in the presence of an inhibitory peptide that specifically prevents clathrin-dependent endocytosis by blocking the binding of dynamin to amphiphysin (Gout et al., 1993; Grabs et al., 1997; Lissin et al., 1998; Marks and McMahon, 1998; Nong et al., 2003). This peptide (DynP) significantly attenuated the ability of SKF-38393 to decrease surface $\beta_{2 / 3}$ subunit levels from $86.5 \pm 2.2 \%$ of control to $96.6 \pm 2.1 \%(p<0.05$, paired $t$ test; $n=4$ ) (Fig. $5 C$ ), and quinpirole from $88.1 \pm 1.2 \%$ of control to $95.6 \pm 2.0 \%$ of control ( $p<0.01$, paired $t$ test; $n=4)$ (Fig. $5 D)$. In contrast, the scrambled control version of this peptide 
A
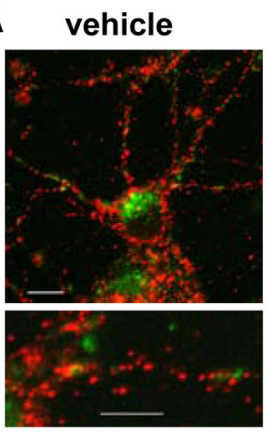
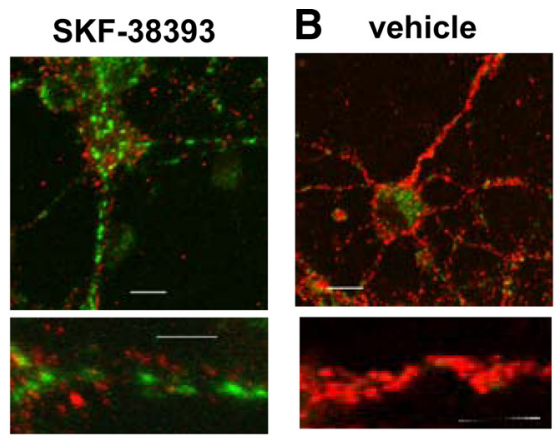

Surface GABA $\beta_{2 / 3} \square$ Internalized GABA $\beta_{2 / 3}$
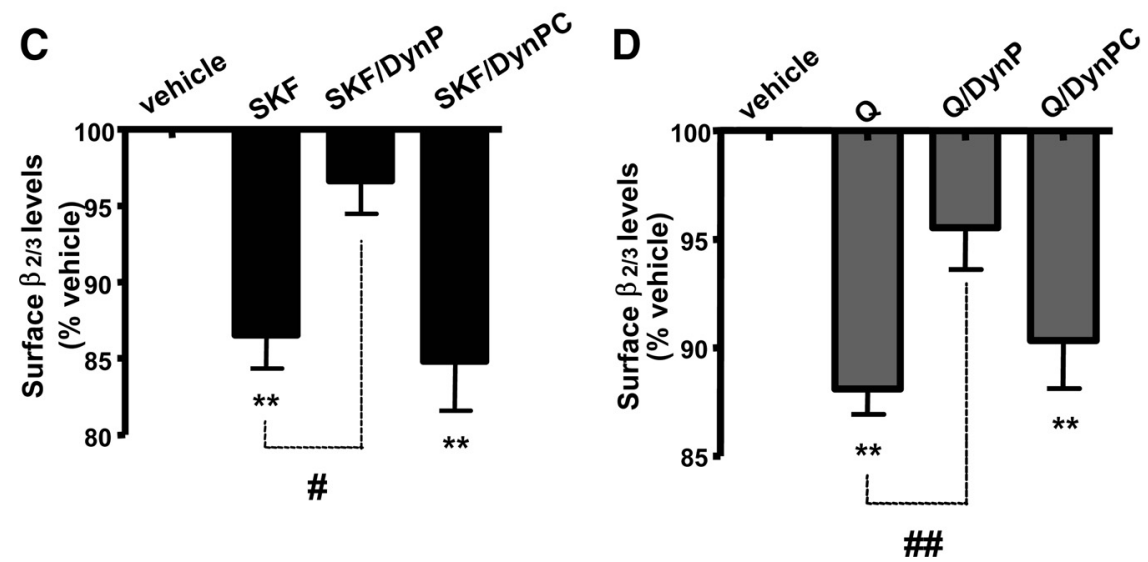

Figure 5. Dopamine receptor activation decreases the cell-surface expression of $\mathrm{GABA}_{A}$ receptors via a dynamin-dependent pathway. $A, B$, Internalization of $G A B A_{A}$ receptors was visualized by staining with $\beta_{2 / 3}$-specific antibody in the presence of vehicle, SKF-38393 (A), or quinpirole $(\boldsymbol{B})$, as described in Materials and Methods. Binding of $\beta_{2 / 3}$-specific antibody to the surface expressed $G A B A_{A}$ receptors was visualized using a secondary anti-mouse lgG coupled to Alexa555 (in red), while binding of the same antibody to internalized receptors was visualized using a secondary anti-mouse lg $\mathrm{G}$ coupled to Alexa488 (in green). Scale bars correspond to $10 \mu \mathrm{m}$. C, The decrease in surface $\beta_{2 / 3}$ subunit levels caused by SKF-38393 (SKF) was significantly attenuated in the presence of a dynamin inhibitory peptide (SKF/DynP), but not in the presence of its scrambled control (SKF/DynPC). D, The decrease in surface $\beta_{2 / 3}$ subunit levels caused by quinpirole (Q) was also significantly attenuated in the presence of a dynamin inhibitory peptide (Q/DynP), but not by its scrambled control (Q/DynPC). Bars represent mean \pm SEM. Statistical analysis was performed using one-way ANOVA with Dunnett post hoc analysis versus control $\left({ }^{*} p<0.05{ }^{* *} p<0.01\right)$ or paired $t$ test $\left({ }^{\#} p<0.05\right.$; $\left.{ }^{\# \#} p<0.01\right)$.

(DynPC) had no significant effect (Fig. 5C,D). SKF-38393 or quinpirole had no effect on total $\beta_{2 / 3}$ levels $(102.3 \pm 2.7 \%$ of control), and this was unaffected by the presence of DynP ( $97.9 \pm$ $4.6 \%$ of control) or DynPC ( $97.0 \pm 5.7 \%$ of control; $p>0.05$, paired $t$ test; $n=4$; data not shown). These results indicate that both $\mathrm{D}_{1}$ Rs and $\mathrm{D}_{2} \mathrm{Rs}$ mediate the reduction in the cell-surface expression of $\beta_{2 / 3}$ subunit-containing $\mathrm{GABA}_{\mathrm{A}}$ receptors, at least in part, through an increase in dynamin-mediated endocytosis.

$D_{1} R s$ and $D_{2} R s$ activate distinct signaling pathways to reduce cell-surface levels of $\mathrm{GABA}_{\mathrm{A}}$ receptors

$D_{1}$ Rs and $D_{2}$ Rs are coexpressed in the embryonic precursors of medium spiny neurons both in vivo and in vitro (Figs. 1,2) (Aizman et al., 2000). Furthermore, both receptor types are activated by dopamine to control the formation of inhibitory synapses and regulate cell-surface expression of $\mathrm{GABA}_{\mathrm{A}}$ receptors. Although evidently impinging on the same functional target, these receptors are likely to activate distinct signaling cascades in these neurons (Greengard, 2001). We used specific activators and inhibitors of a number of intracellular signaling molecules to characterize these signaling cascades.

cAMP/PKA signaling

$\mathrm{D}_{1}$ Rs and $\mathrm{D}_{2}$ Rs are classified by their positive or negative coupling to $\mathrm{G}_{\mathrm{s}}$ or $\mathrm{G}_{\mathrm{i} / \mathrm{o}}$ G-proteins that regulate adenylyl cyclase (AC); it is this coupling that is responsible for a large number of downstream cellular effects (Missale et al., 1998). To determine whether AC mediates regulation of surface $\mathrm{GABA}_{\mathrm{A}}$ receptors by $\mathrm{D}_{1}$ Rs or $\mathrm{D}_{2} \mathrm{Rs}$, we examined the effects of forskolin, an activator of AC (Awad et al., 1983; Laurenza et al., 1989). Neurons were pretreated with vehicle or forskolin $(10 \mu \mathrm{M})$ for $10 \mathrm{~min}$, after which $D_{1}$ Rs and $D_{2}$ Rs were activated with SKF-38393 (1 nM) or quinpirole (100 $\mathrm{nM}$ ) in the absence or presence of forskolin. Changes in the surface and total levels of $\beta_{2 / 3}$ subunits were examined using cellsurface ELISA. We demonstrate that forskolin treatment alone caused an apparent increase in $\beta_{2 / 3}$ surface levels to $108.2 \pm$ $3.3 \%$ of control, although this was not statistically significant ( $p>0.05$, one-way ANOVA; $n=4$; data not shown). The decrease in surface $\beta_{2 / 3}$ levels after $30 \mathrm{~min}$ treatment with SKF-38393 (83.5 $\pm 3.1 \%$ of control, $p<0.05$, one-way ANOVA; $n=4$ ) (Fig. $6 \mathrm{~A}, \mathrm{SKF}$ ) was significantly attenuated by forskolin $(98.5 \pm 5.1 \%$ of control, $p<0.05$; paired $t$ test; $n=4$ ) (Fig. $6 \mathrm{~A}, \mathrm{SKF} / \mathrm{F})$. In contrast, the decrease observed in the presence of quinpirole $(85.2 \pm 3.9 \%$ of control, $p<0.05$, oneway ANOVA; $n=5$ ) (Fig. $6 \mathrm{~A}, \mathrm{Q}$ ) was unaffected $(88.4 \pm 4.3 \%$ of control, $p<$ 0.05 , one-way ANOVA; $n=5$ ) (Fig. $6 \mathrm{~A}$, $\mathrm{Q} / \mathrm{F}$ ) by the presence of forskolin. Forskolin had no significant effect on the total levels of $\beta_{2 / 3}$ subunits in the absence $(105.8 \pm 4.4 \%$ of control, $p>0.05$, oneway ANOVA; $n=4)$ or presence of SKF$38393(113.5 \pm 3.2 \%$ of control; $p>0.05$, one-way ANOVA; $n=4$ ) or quinpirole $(105.1 \pm 5.1 \%$ of control, $p>0.05$, one-way ANOVA; $n=5$, data not shown). These results suggest that stimulation of AC by forskolin occludes the ability of $\mathrm{D}_{1}$ Rs to activate $\mathrm{AC}$ and regulate $\mathrm{GABA}_{\mathrm{A}}$ receptor levels, without affecting the $\mathrm{D}_{2} \mathrm{R}$-dependent regulation of these receptors.

To test whether PKA participates as a downstream component of $\mathrm{D}_{1} \mathrm{R} / \mathrm{AC}$ signaling cascade, we treated striatal neurons with the selective PKA activator 8-bromo-cAMP $(10 \mu \mathrm{M})$ in the absence or presence of SKF-38393 (1 nM) or quinpirole (100 nM) for 30 min. Direct activation of PKA with 8-bromo-cAMP caused a small but significant increase in the surface expression of $\beta_{2 / 3}$ subunit to $112.8 \pm 4.0 \%$ of control $(p<0.05$, one-way ANOVA with Dunnett post hoc test; $n=5$; data not shown), and abolished $(101.4 \pm 3.1 \%$ of control, $p<0.05$; paired $t$ test; $n=5$ ) (Fig. $6 B$, SKF/cAMP) the SKF-38393-dependent decrease in $\beta_{2 / 3}$ levels to $89.0 \pm 2.9 \%$ of control ( $p<0.05$; one-way ANOVA with Dunnett post hoc analysis; $n=5$ ) (Fig. $6 B$, SKF). However, quinpirole-dependent decrease in surface $\beta_{2 / 3}$ levels $(81.0 \pm$ $7.3 \%$ of control, $p<0.05$, one-way ANOVA with Dunnett post hoc analysis; $n=4$ ) (Fig. $6 \mathrm{~B}, \mathrm{Q}$ ) was unaffected by 8 -bromocAMP $(82.6 \pm 6.3 \%$ of control, $p<0.05$, one-way ANOVA with Dunnett post hoc analysis; $n=4$ ) (Fig. $6 \mathrm{~B}, \mathrm{Q} / \mathrm{cAMP}$ ). The total levels of $\beta_{2 / 3}$ subunits in the absence (101.2 $\pm 8.9 \%$ of control) or presence of SKF-38393 (118.2 $\pm 10.4 \%$ of control; $p>0.05$, 
A

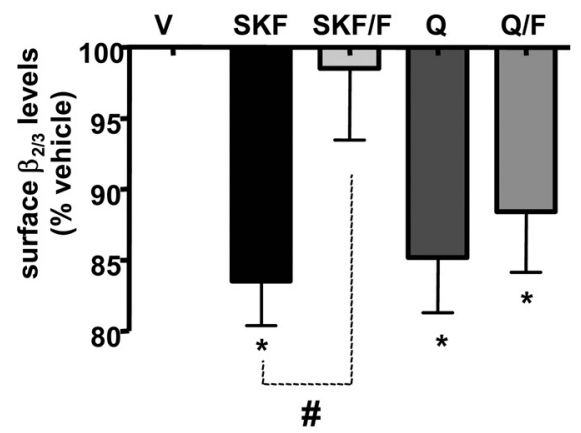

C

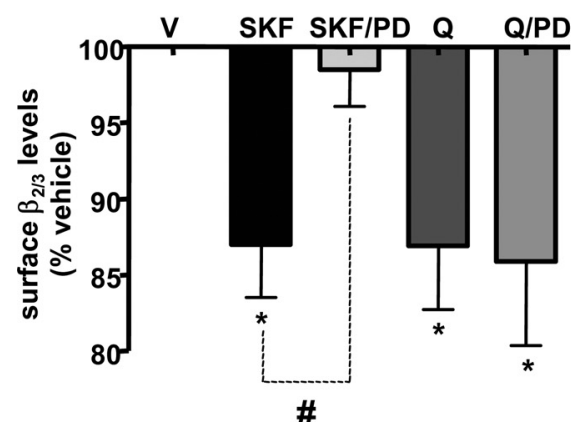

E

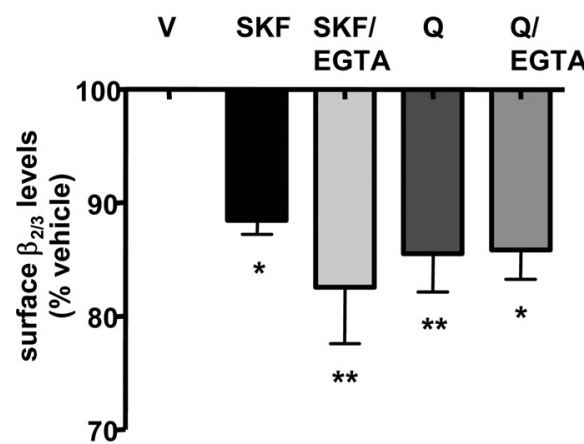

G

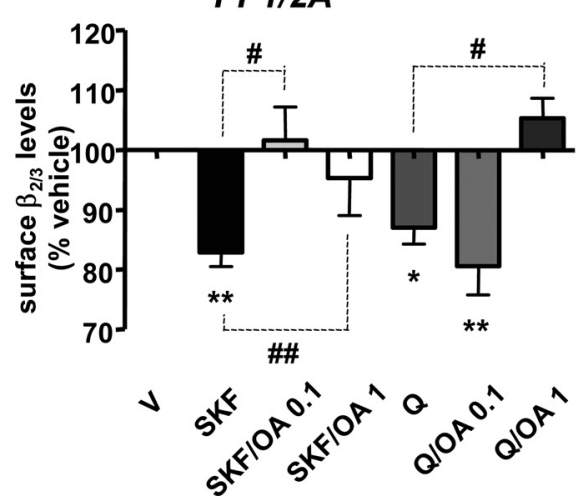

B

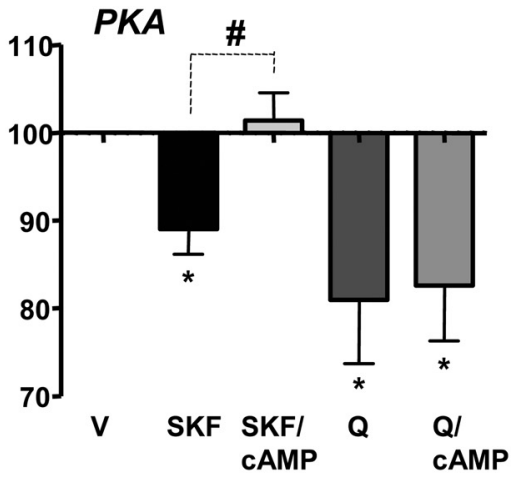

D $\quad P K C$

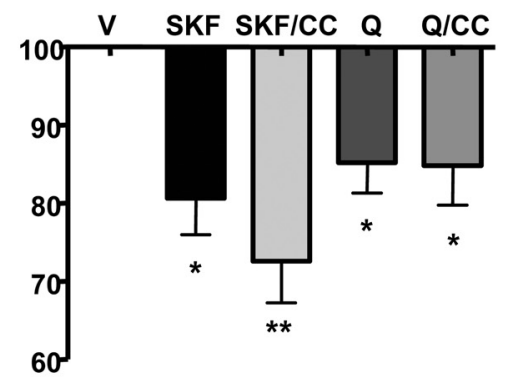

$\mathbf{F}$

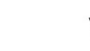

Intracellular $\left[\mathrm{Ca}^{2+}\right]$

V SKF SKFI Q Q BAPTA

BAPTA

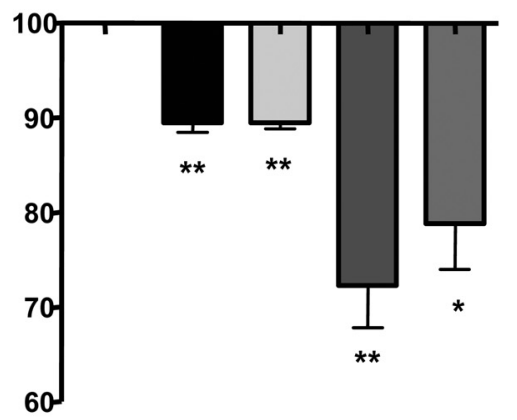

$\mathbf{H}$

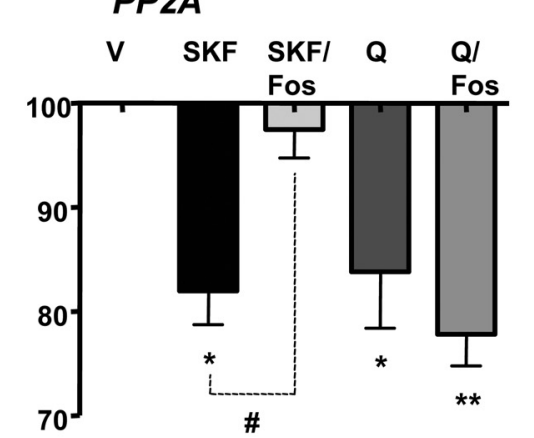

one-way ANOVA; $n=5$ ) or quinpirole $(103.5 \pm 10.3 \%$ of control, $p>0.05$, oneway ANOVA with Dunnett post hoc analysis; $n=4$ ) were also unaffected by 8-bromo-cAMP (SKF/8BrcAMP: $107.1 \pm$ $12.4 \%$ of control; quinpirole/8BrcAMP: $108.3 \pm 7.2 \%$ of control, $p>0.05$, oneway ANOVA; $n=5$ and $n=4$, respectively, data not shown).

To further support the role of PKA in $D_{1} R / A C$ signaling pathway, we treated striatal neurons with the PKA inhibitor $\mathrm{KT}-5720(5 \mu \mathrm{M})$ in the absence or presence of SKF-38393 (1 nM) for $30 \mathrm{~min}$. While PKA inhibition with KT-5720 alone had no significant effect on surface $\beta_{2 / 3}$ levels ( $96.1 \pm 6.1 \%$ of control; $p>$ 0.05 , one-way ANOVA; $n=3$ ), it significantly enhanced $\mathrm{D}_{1} \mathrm{R}$-mediated decrease in $\beta_{2 / 3}$ cell-surface expression from $87.1 \pm$ $4.2 \%$ of control to $77.3 \pm 5.5 \%$ of control ( $p=0.024$, paired $t$ test; $n=3$, data not shown). Total $\beta_{2 / 3}$ levels were unaffected in the presence of KT-5720 $(99.5 \pm 2.1 \%$ of control, $p>0.05$, one-way ANOVA; $n=3$ ) or SKF $(115.8 \pm 6.5 \%$ of control) or both ( $114.7 \pm 8.1 \%$ of control; $p>0.05$, one-way ANOVA; $n=3$; data not shown)

\section{MEK/ERK1 and ERK2 signaling}

$\mathrm{D}_{1}$ Rs, but not $\mathrm{D}_{2}$ Rs, are known to stimulate MAP kinases ERK1 and ERK2 (Valjent et al., 2005) via activation of an upstream kinase, MAP kinase/ERK kinase (MEK) (Sefton, 2001). We have observed that SKF-38393 but not quinpirole significantly increased the phosphorylation/activity of ERK1/2 after 30 min treatment (data not shown). Furthermore, we found that inhibition of MAP kinase kinase, MEK, with PD-98059 (50 $\mu \mathrm{M})$ attenuated the ability of SKF-38393 to decrease $\mathrm{GABA}_{\mathrm{A}}$ receptor cell-surface levels from $87.0 \pm 3.5 \%$ (Fig. $6 C, \mathrm{SKF}$ ) to $98.5 \pm$

surface levels. $\boldsymbol{E}$, Buffering of extracellular calcium with EGTA (EGTA) had no effect on SKF-38393-dependent (SKF vs SKF/ EGTA), or quinpirole-dependent ( $Q$ vs $Q / E G T A$ ) decrease in $\beta_{2 / 3}$ surface levels. $\boldsymbol{F}$, Buffering of intracellular calcium with BAPTA-AM (BAPTA) had no effect on SKF-38393-dependent (SKF vs SKF/BAPTA), or quinpirole-dependent ( $Q$ vs $Q / B A P T A$ ) decrease in $\beta_{2 / 3}$ surface levels. G, The decrease in surface $\beta_{2 / 3}$ levels caused by SKF-38393 (SKF), but not quinpirole (Q) was abolished by a low concentration of okadaic acid $(0.1 \mu \mathrm{m}$; SKF/OA 0.1, Q/0A 0.1, respectively), while both SKF-38393dependent (SKF) and quinpirole-dependent (Q) decreases were abolished by a high concentration of okadaic acid $(1 \mu \mathrm{M}$; SKF/OA 1, Q/OA 1, respectively). $\boldsymbol{H}$, The effect of SKF-38393 (SKF), but not quinpirole (Q), was significantly attenuated by fostriecin (SKF/Fos, Q/Fos, respectively). Bars represent mean \pm SEM. Statistical analysis was performed using one-way ANOVA with either a Dunnettposthocanalysis versus control $\left({ }^{*} p<0.05 ;{ }^{* *} p<0.01\right.$ ) or paired $t$ test $\left({ }^{\#} p<0.05\right.$; $\left.\# p<0.01\right)$.

Figure 6. $D_{1} R$-dependent reduction of the $G A B A_{A}$ receptor levels expressed at the cell surface is mediated by the activities of PKA, ERK1 and ERK2, and PP2A, whereas $D_{2}$ R-dependent decrease is mediated by the activity of PP1. $A$, The effect of SKF-38393 (SKF), but not quinpirole (Q), was occluded by a direct activation of adenylyl cyclase (AC) with forskolin (SKF/F, $Q / F$, respectively). $\boldsymbol{B}$, The effect of SKF-38393 (SKF), but not quinpirole (Q), was also occluded by a direct activation of protein kinase $A$ (PKA) with 8-bromo-CAMP (SKF/CAMP, Q/CAMP, respectively). C, The effect of SKF-38393 (SKF), but not quinpirole (Q) was attenuated by inhibition of ERK kinases (ERK1 \& 2) with PD-98059 (SKF/PD, Q/PD, respectively). D, The inhibition of protein kinase C (PKC) by calphostin C (CC) had no effect on SKF-38393-dependent (SKF vs SKF/CC), or quinpirole-dependent (Q vs Q/CC) decrease in $\beta_{2 / 3}$ 
$2.5 \%$ of control ( $p<0.05$, paired $t$ test, $n=7$ ) (Fig. $6 C$, SKF/PD). In contrast, PD-98059 had no significant effect quinpiroledependent regulation: quinpirole decreased surface $\beta_{2 / 3}$ levels to $86.9 \pm 4.2 \%$ of control (Fig. $6 C, Q$ ) and to $85.9 \pm 5.5 \%$ of control in the presence of PD-98059 ( $p>0.05$, paired $t$ test, $n=6$ ) (Fig. $6 C, \mathrm{Q} / \mathrm{PD})$. PD-98059 did not significantly affect cell-surface $\beta_{2 / 3}$ levels when added alone (data not shown).

\section{PKC signaling}

$\mathrm{PKC}$ is known to regulate surface levels of $\mathrm{GABA}_{\mathrm{A}}$ receptors in cultured hippocampal and cortical neurons by inhibiting the recycling of internalized receptors to the plasma membrane (Connolly et al., 1999). To determine whether PKC is involved in modulating surface levels of $\mathrm{GABA}_{\mathrm{A}}$ receptors in cultured striatal neurons, we used calphostin $\mathrm{C}(0.2 \mu \mathrm{M})$, a PKC inhibitor that inhibits both typical and atypical isoforms of this enzyme (Kobayashi et al., 1989). In the presence of calphostin $C$ alone, surface $\beta_{2 / 3}$ levels were unaffected $(97.5 \pm 10.1 \%$ of control; $p>0.05$, one-way ANOVA; $n=5$; data not shown). A significant reduction in surface $\beta_{2 / 3}$ levels by SKF-38393 to $80.7 \pm 4.7 \%$ of control ( $p<$ 0.05 , one-way ANOVA; $n=5$ ) (Fig. $6 D, \mathrm{SKF}$ ), or by quinpirole to $85.2 \pm 3.9 \%$ of control ( $p<0.05$, one-way ANOVA; $n=5$ ) (Fig. $6 D, Q)$, was unaffected by calphostin C [72.6 $\pm 5.3 \%$ of control, $p>0.05$, paired $t$ test; $n=5$ (Fig. $6 D$, SKF/CC); and $84.8 \pm 5.1 \%$ of control, $p>0.05$, paired $t$ test; $n=5$ (Fig. $6 D, \mathrm{Q} / C C$ )]. Total $\beta_{2 / 3}$ levels remained unchanged following the treatment with calphostin $\mathrm{C}$ alone, or in combination with SKF-38393 or quinpirole (data not shown). Thus, PKC activity is not required for either $D_{1} R$ - or $D_{2} R$-dependent regulation of surface $\beta_{2 / 3}$ levels in the embryonic striatal neurons.

\section{$\mathrm{Ca}^{2+}$-dependent signaling}

$\mathrm{Ca}^{2+}$ plays a fundamental role as an intracellular signal by directly regulating the activity of a large number of signaling molecules including protein kinases and phosphatases (Walaas and Greengard, 1991), which have been previously implicated in both $\mathrm{D}_{1} \mathrm{R}$ (Surmeier et al., 1995; Tang and Bezprozvanny, 2004; Iwakura et al., 2008) and $\mathrm{D}_{2} \mathrm{R}$ (Surmeier et al., 1992; Aizman et al., 2000; Tang and Bezprozvanny, 2004) signaling in striatal neurons. To examine a possible requirement for $\mathrm{Ca}^{2+}$ and $\mathrm{Ca}^{2+}$ dependent signaling pathways in the regulation of $\mathrm{GABA}_{\mathrm{A}}$ receptor surface levels, we selectively buffered extracellular or intracellular $\mathrm{Ca}^{2+}$ before the activation of dopamine receptors. To examine the contribution of extracellular $\mathrm{Ca}^{2+}$, we applied a $\mathrm{Ca}^{2+}$ chelating agent EGTA $(1 \mathrm{~mm})$. We demonstrate that EGTA had no effect on the surface levels of $\beta_{2 / 3}$ subunits ( $p>0.05$, one-way ANOVA with Dunnett post hoc analysis; $n=5$; data not shown). Importantly, SKF-38393-dependent $(88.5 \pm 1.2 \%$ of control, $p<$ 0.05 , one-way ANOVA with Dunnett post hoc analysis; $n=5$ ) (Fig. $6 E, \mathrm{SKF})$ and quinpirole-dependent $(85.5 \pm 3.4 \%$ of control, $p<$ 0.05 , one-way ANOVA with Dunnett post hoc analysis; $n=4$ ) (Fig. $6 E, Q)$ decreases in surface $\beta_{2 / 3}$ levels were unaffected by the presence of EGTA ( $82.5 \pm 5.0 \%$ of control, SKF/EGTA, and $85.8 \pm 2.6 \%$ of control, Q/EGTA, $p<0.05$, one-way ANOVA with Dunnett post hoc analysis; $n=5$ and $n=4$, respectively) (Fig. $6 E$ ). We also demonstrate that changes in total $\beta_{2 / 3}$ levels were not statistically significant following the treatment with EGTA alone or in combination with SKF-38393 or quinpirole (data not shown).

To buffer intracellular $\mathrm{Ca}^{2+}$, we applied a high-affinity, membrane-permeable $\mathrm{Ca}^{2+}$ chelator, BAPTA-AM $(25 \mu \mathrm{M})$. BAPTA-AM treatment alone had no effect on surface $\beta_{2 / 3}$ levels ( $p>0.05$, one-way ANOVA; $n=3$; data not shown). Neither the SKF-38393-dependent $(89.5 \pm 1.0 \%$ of control, $p<0.01$, one- way ANOVA; $n=3$ ) (Fig. $6 F, \mathrm{SKF}$ ), or quinpirole-dependent $(72.3 \pm 4.5 \%$ of control, $p<0.05$, one-way ANOVA with Dunnett post hoc analysis; $n=5$ ) (Fig. $6 F, Q$ ) decrease in surface $\beta_{2 / 3}$ levels was affected by BAPTA-AM [89.5 $\pm 0.7 \%$ of control, $p<0.01$, one-way ANOVA; $n=3$ (Fig. $6 F$, SKF/BAPTA); and 78.9 $\pm 4.9 \%$ of control $p<0.05$, one-way ANOVA; $n=5$ (Fig. $6 F, \mathrm{Q} / \mathrm{BAPTA}$ )]. Total $\beta_{2 / 3}$ levels were not significantly affected following treatment with BAPTA alone or in combination with SKF-38393, or quinpirole (data not shown). Together, these data suggest that changes in $\left[\mathrm{Ca}^{2+}\right]_{\mathrm{i}}$ and $\mathrm{Ca}^{2+}$-dependent signaling proteins are not involved in the regulation of surface $\mathrm{GABA}_{\mathrm{A}}$ receptors by $\mathrm{D}_{1}$ Rs or $\mathrm{D}_{2}$ Rs.

\section{Protein phosphatase signaling}

Protein phosphatases PP1 and PP2A have been shown previously to associate with $\mathrm{GABA}_{\mathrm{A}}$ receptors (Jovanovic et al., 2004; Terunuma et al., 2004). To investigate whether their activity is required for $D_{1} R$ - or $D_{2} R$-dependent regulation of surface $\beta_{2 / 3}$ levels, we incubated striatal neurons with $0.1 \mu \mathrm{M}$ okadaic acid, a concentration sufficient to block PP2A activity, or with $1 \mu \mathrm{M}$ okadaic acid, a concentration that inhibits both PP1 and PP2A (Nishi et al., 1997). We demonstrate that treatments with both 0.1 and $1 \mu \mathrm{M}$ okadaic acid significantly attenuated the ability of SKF-38393 to reduce $\beta_{2 / 3}$ surface levels from $82.1 \pm 5.9 \%$ of control ( $p<0.05$, one-way ANOVA; $n=5$ ) (Fig. 6G, SKF) to $101.6 \pm 5.6 \%$ of control, and to $95.3 \pm 6.2 \%$ of control $(p<0.05$, paired $t$ test, $n=3$, SKF/OA 0.1 , or $n=4$, SKF/OA 1 , respectively) (Fig. $6 G$ ). In contrast, quinpirole-dependent decrease in surface $\beta_{2 / 3}$ levels $(87.0 \pm 2.7 \%$ of control, $p<0.05$, one-way ANOVA; $n=5)$ (Fig. $6 G, Q$ ) was unaffected by $0.1 \mu \mathrm{M}$ okadaic acid $(80.6 \pm 4.7 \%$ of control, $p>0.05$, paired $t$ test, $n=5$ ) (Fig. 6G, Q/OA 0.1), but significantly attenuated by $1 \mu \mathrm{M}$ okadaic acid ( $105.3 \pm 3.4 \%$ of control, $p<0.01$, paired $t$ test, $n=5$ ) (Fig. 6G, Q/OA 1). Okadaic acid had no significant effect on surface $\beta_{2 / 3}$ levels at either concentration tested (data not shown). Total $\beta_{2 / 3}$ levels were not significantly affected following treatment with okadaic acid alone or in combination with SKF-38393 or quinpirole (data not shown).

The role of PP2A was confirmed using a selective PP2A antagonist fostriecin (100 nM) (Stampwala et al., 1983). The ability of SKF-38393 to decrease $\beta_{2 / 3}$ subunit cell-surface levels (82.0 \pm $3.3 \%$ of control, one-way ANOVA; $n=4$ ) (Fig. $6 H$, SKF) was significantly attenuated by fostriecin $(97.5 \pm 2.7 \%$ of control, $p<$ 0.05 , paired $t$ test, $n=4$ ) (Fig. $6 H, \mathrm{SKF} / \mathrm{Fos}$ ). In contrast, quinpirole-dependent decrease in surface $\beta_{2 / 3}$ levels (83.8 \pm $5.4 \%$ of control, $p<0.05$, one-way ANOVA; $n=3$ ) (Fig. $6 H$, Q) was unaffected by fostriecin (77.8 $\pm 3.0 \%$ of control, $p>0.05$, paired $t$ test, $n=3$ ) (Fig. $6 H$ ). Thus, $\mathrm{D}_{1} \mathrm{R}$-dependent regulation of surface $\mathrm{GABA}_{\mathrm{A}}$ receptors operates via activation of AC/PKA signaling pathway, ERK kinases, and PP2A, while $\mathrm{D}_{2} \mathrm{R}$-dependent regulation requires the activity of PP1 in embryonic striatal neurons.

\section{$D_{1} R$ and $D_{2} R$ activation transiently dephosphorylates $\mathrm{GABA}_{\mathrm{A}}$ receptors}

Given that $D_{1} R$ - and $D_{2} R$-dependent regulation of surface $\mathrm{GABA}_{\mathrm{A}}$ receptors requires the activity of protein phosphatases PP2A and PP1, we hypothesized that $\mathrm{GABA}_{\mathrm{A}}$ receptor themselves may be dephosphorylated by these phosphatase to trigger their endocytosis, as already demonstrated in the adult striatal tissue (Kittler and Moss, 2003; Kittler et al., 2005, 2008; Chen et al., 2006). Thus we used a phosphorylation state-specific antibody [anti-P $\beta$ antibody (Jovanovic et al., 2004)], which selectively binds to P-Ser409 in the $\beta 1$ and $\beta 3$, and P-Ser410 in the $\beta 2$ subunit of $\mathrm{GABA}_{\mathrm{A}}$ receptors, to determine the state of phosphorylation of these receptors in response to $D_{1} R$ or $D_{2} R$ activation. Using quantitative 
immunoblotting, we demonstrate that SKF caused a rapid dephosphorylation of $\beta$ subunits $(75.9 \pm 4.3 \%$ of control, $p<$ 0.05 , paired $t$ test; $n=3$ ) (Fig. $7 A$, SKF), which was abolished in the presence of PP2A inhibitor fostriecin $(120.8 \pm 11.6 \%$ of control, $p<0.05$, paired $t$ test; $n=3$ ) (Fig. 7A, SKF/Fos). Additionally, fostriecin caused an apparent increase in the basal levels of $\beta$ phosphorylation to $125.3 \pm 21.9 \%$ of control $(p>0.05$, paired $t$ test; $n=3$ ) (Fig. 7A, Fos). Interestingly, MEK inhibitor PD-98059 (50 $\mu \mathrm{M})$ also abolished dephosphorylation of $\beta$ subunits by SKF $(124.3 \pm 11.0 \%$ of control, $p<0.05$, paired $t$ test; $n=3$ ) (Fig. $7 A$, $\mathrm{SKF} / \mathrm{PD})$, and produced an apparent increase in $\beta$ phosphorylation (125.7 \pm $14.0 \%$ of control, $p>0.05$, paired $t$ test; $n=3$ ) (Fig. 7A, PD) on its own. Total levels were not significantly affected by SKF-38393 or any other treatment (data not shown). Activation of $\mathrm{D}_{2}$ Rs with quinpirole caused a significant decrease in phosphorylation of $\beta$ subunit to $79.3 \pm 6.2 \%$ of control $(p<0.05$, paired $t$ test; $n=4$ ) (Fig. $7 B, \mathrm{Q})$. Pretreatment with the PP1 inhibitor okadaic acid $(1 \mu \mathrm{M})$ increased significantly the basal levels of $\beta$ subunit phosphorylation to $726.6 \pm 76.4 \%$ of control $(p<$ 0.05 , paired $t$ test; $n=4)$ (Fig. $7 B, \mathrm{OA}$ ), and completely abolished dephosphorylation of $\beta$ subunits caused by quinpirole $(664.7 \pm 110.4 \%$ of control, $p>$ 0.05 , paired $t$ test; $n=4$ ) (Fig. $7 B$, $\mathrm{Q} / \mathrm{OA})$. Thus, it appears that PP2A and $\mathrm{PP} 1$ dephosphorylate $\mathrm{GABA}_{\mathrm{A}}$ receptor $\beta$ subunits in response to $D_{1} R$ and $D_{2} R$ activation, respectively.

To characterize further PP1- and PP2A-mediated dephosphorylation of $\mathrm{GABA}_{\mathrm{A}}$ receptors, we performed in vitro phosphatase assays using purified enzymes, catalytic subunit of PP1 (PP1c), PP2A (PP2A), and calcineurin, and purified phosphorylated GST-fusion proteins containing the intracellular TM3-4 loops of the $\beta 1-3$ subunits (see Materials and Methods). In these experiments, the initial rates of dephosphorylation of $\left[{ }^{32} \mathrm{P}\right]$ phospho-GST- $\beta 1-3$ subunits, and $\left[{ }^{32} \mathrm{P}\right]$-phospho-DARPP-32 or $\left[{ }^{32} \mathrm{P}\right]$-phosphorylase a used as reference substrates, were assessed by measuring the release of phosphate (Table 1). Compared to the reference substrates, all three $\beta$ subunits appeared to be good substrates for PP1c and PP2A, but poor substrates for calcineurin. These initial results were extended by a kinetic analysis of $\left[{ }^{32} \mathrm{P}\right]$-phospho-GST- $\beta 1-3$ dephosphorylation with PP1c and PP2A (Table 2). Two kinetic parameters, $K_{\mathrm{m}}$ (the apparent affinity for substrate), and $V_{\max }$ (the rate), were determined demonstrating a high affinity and rapid dephosphorylation of all three $\beta$ subunits by PP1c and PP2A.

Importantly, activation of dopamine receptors leads to a significant but transient dephosphorylation of $\mathrm{GABA}_{\mathrm{A}}$ receptor $\beta$ subunits. We demonstrate that application of SKF-38393 (1 nM), caused a significant decrease in phosphorylation of the $\beta$ subunits at $10 \mathrm{~min}$ to $87.0 \pm 3.3 \%$ of control $(p<0.05$, one-way ANOVA; $n=3$ ), and, at $60 \mathrm{~min}$ to $86.5 \pm 2.5 \%$ of control ( $p<$
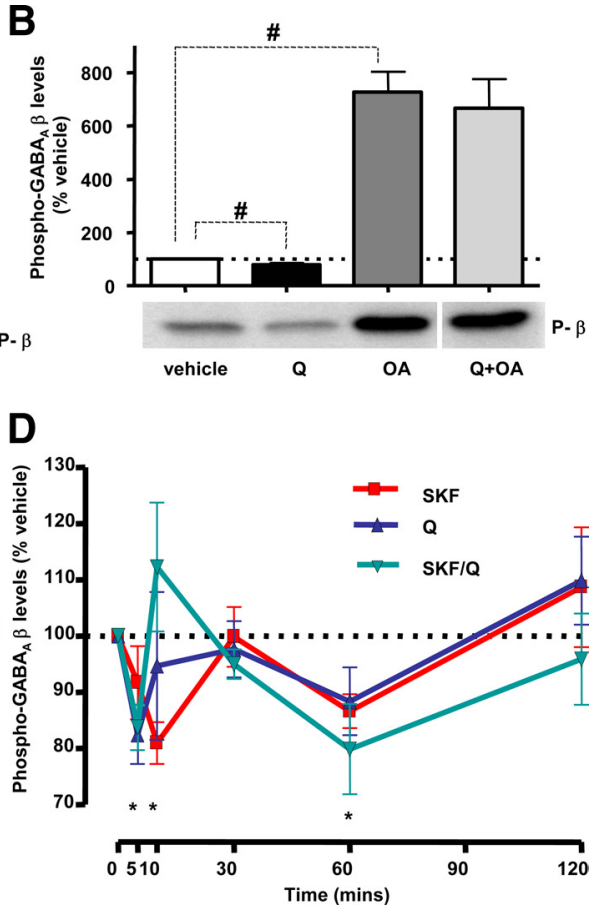

Figure 7. $\quad D_{1} R$ and $D_{2} R$ activation leads to a transient dephosphorylation of $G A B A_{A}$ receptor $\beta$ subunits. $A$, Treatment with , appropriate controls treated with the vehicle $(100 \%$; $\boldsymbol{D})$ show a transient decrease in the phosphorylation state of the $\beta$ subunits ingreen), or both (SKF/Q in blue). Values represent mean \pm SEM. Statistical analysis was performed using one-way ANOVA with either a Dunnett post hoc analysis versus control ( $\left.{ }^{*} p<0.05\right)$ or paired $t$ test $\left({ }^{\#} p<0.05\right)$.

0.05, paired $t$ test; $n=5$ ) (Fig. 7C, $D, \mathrm{SKF}$ ), which was reversed to the basal levels at later time points. The application of quinpirole $(100 \mathrm{nM})$ caused a significant decrease in phosphorylation of the $\beta$ subunits within 5 min to $82.5 \pm 5.2 \%$ of control $(p<0.05$, one-way ANOVA; $n=4)$, but only an apparent decrease at 60 min to $88.4 \pm 6.0 \%$ of control $(p>0.05$, one-way ANOVA; $n=4)$ (Fig. 7C,D, Q). Importantly, when both SKF-38393 and quinpirole were applied at the same time, we observed a similar transient decrease in $\beta$ subunit phosphorylation to $83.7 \pm 4.0 \%$ of control at $5 \mathrm{~min}$, and to $79.9 \pm 8.0 \%$ of control at $60 \mathrm{~min}$, which was reversed to the basal levels at later time points $(p<0.05$, one-way ANOVA; $n=4$ ) (Fig. 7C, $D, \mathrm{SKF} / \mathrm{Q}$ ).

Thus, dopamine receptor activity exerts its powerful control of inhibitory synaptogenesis in the developing striatum by regulating the levels of $\mathrm{GABA}_{\mathrm{A}}$ receptors expressed at the cell surface through a mechanism that involves transient dephosphorylation of these receptors.

\section{Discussion}

With its essential role as the major input area to the basal ganglia and its dysfunction in the pathogenesis of diseases such as Parkinson's and Huntington's diseases, the striatum represents one of the primary subjects of scientific interest. While there is increasing research into the function of the adult striatum, very little work has focused on its development. The striatum receives considerable dopaminergic input from the substantia nigra early 


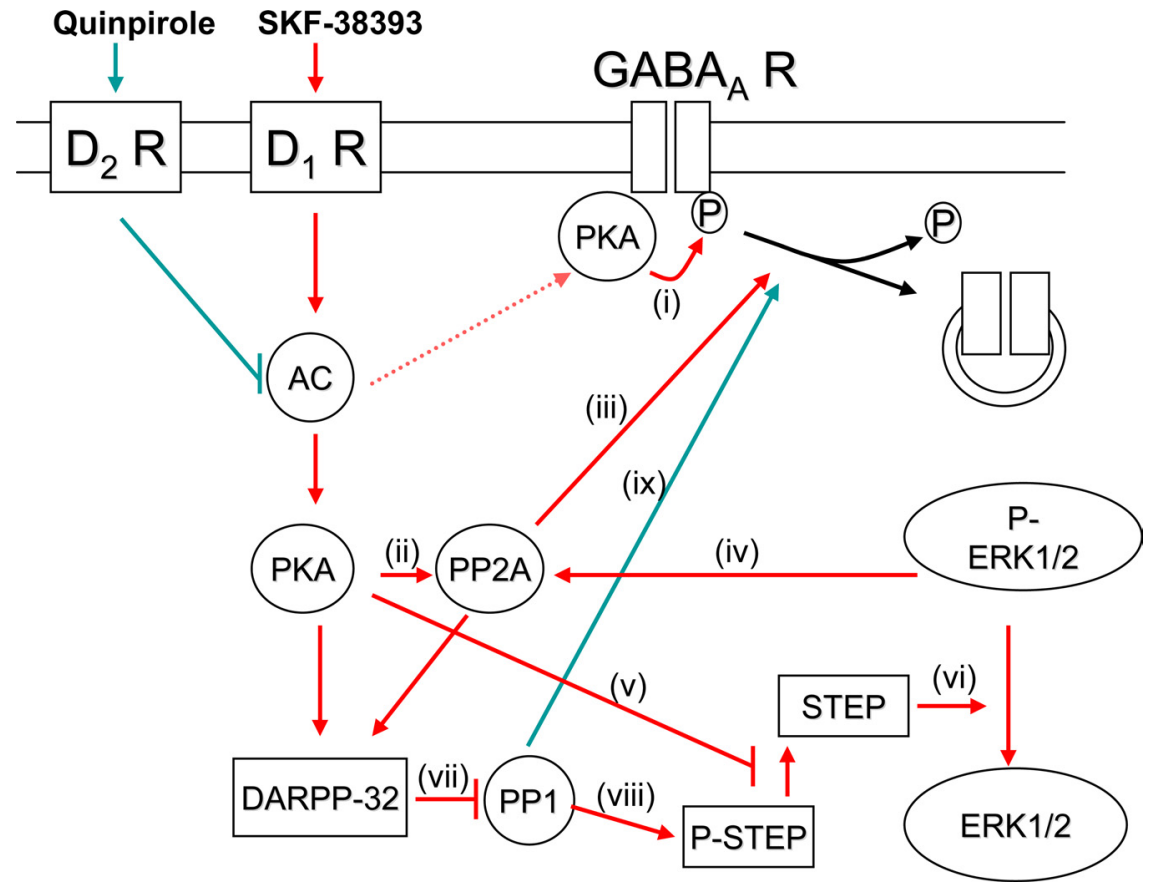

Figure 8. Functional cross talk between $D_{1} R$ and $D_{2} R$ signaling pathways regulating $G A B A_{A}$ receptors in the embryonic striatal neurons. Activation of D1R with SKF-38393 (in red) leads to activation of adenylyl cyclase (AC) resulting in activation of conceivably two segregated pools of protein kinase $A(P K A)$. The first pool of PKA is associated with $G_{A B A_{A}}$ receptors leading to a rapid phosphorylation of $G_{A B A_{A}}$ receptors (i). The second pool of PKA is more distal and unable to associate with $G_{A B A_{A}}$ receptors. This pool of PKA directly phosphorylates and activates protein phosphatase 2A (PP2A, ii). Activated PP2A associates with and dephosphorylates $G A B A_{A}$ receptors, promoting their internalization from the cell surface (iii). The ability of PP2A to dephosphorylate $G_{A B A}$ receptors is likely to be enhanced due to ERK1/2-mediated phosphorylation and activation of PP2A (iv). ERK1/2 can be activated by two different signaling pathways both involving PKA. First, PKA can directly phosphorylate and thus inactivate striatal enriched phosphatase (STEP, $\boldsymbol{v}$ ). In this way, STEP is no longer able to dephosphorylate and deactivate ERK1/2. Second, PKA can lead to the activation of DARPP-32, an inhibitor of protein phosphatase 1 (PP1, vii). Inactivated PP1 cannot dephosphorylate and activate STEP, which is then unable to dephosphorylate ERK1/2 (viii). Both of these pathways lead to an increase in the level of phosphorylated ERK1/2, which acts on PP2A to promote dephosphorylation of $G A B A_{A}$ receptors. Activation of $D_{2}$ Rs by quinpirole (in green) leads to a dephosphorylation of $G A B A_{A}$ receptors and their internalization by inhibiting $A C$. Inhibition of $A C$ leads to a reduction in the activation of PKA and consequently to a reduction in PKA-mediated phosphorylation of $\mathrm{ABB}_{A}$ receptors $(i)$. At the same time however, inhibition of AC may lead to a decrease in DARPP-32 activity and thus activation of PP1 (vii). Activated PP1 is then capable of associating with $\mathrm{GABA}_{A}$ receptors and mediating their dephosphorylation and subsequent internalization (ix).

leads to a reduction in the frequency of spontaneous $\mathrm{GABA}_{\mathrm{A}}$ receptor-mediated synaptic potentials (mIPSPs), as well as a reduction in their amplitudes. The latter also correlates with a reduction in the number of $\mathrm{GABA}_{\mathrm{A}}$ receptors present at the postsynaptic membrane (Nusser et al., 1997, 1998). Accordingly, immunocytochemical analysis of $\mathrm{GABA}_{\mathrm{A}}$ receptorpositive clusters, as well as biochemical measurements of cell-surface levels of $\mathrm{GABA}_{\mathrm{A}}$ receptors using ELISA, clearly demonstrates that this is indeed the case. However, it is important to note that despite the reduction in size, the overall number of postsynaptic $\mathrm{GABA}_{\mathrm{A}}$ receptor clusters, as well as the size and number of presynaptic VIAAT-1-positive terminals, remains unaltered. This suggests that formation and/or stability of functional GABAergic synapses may depend on the size of $\mathrm{GABA}_{\mathrm{A}}$ receptor clusters present at the postsynaptic membrane, in addition to the type of $\mathrm{GABA}_{\mathrm{A}}$ receptors that form these clusters. In support of this hypothesis is the observation that, in many brain regions, extrasynaptic clusters of $\mathrm{GABA}_{\mathrm{A}}$ receptors are significantly smaller than their synaptic counterparts (Christie et al., 2002a,b). Overall, the ability of striatal neurons to form functional synaptic contacts with each other appears to be restricted by dopamine during development. Dopamine is known to decrease the number of glutamatergic synapses present on $\mathrm{D}_{2} \mathrm{R}$-containing medium spiny neurons in the adult striatum, since the depletion of dopamine in the rat models of Parkinson's disease leads to an increase in the number of synapses (Day et al., 2006). To-

in development, and the evidence suggests that dopamine may play an important role. For example, in utero exposure to cocaine profoundly affects development of neuron dendrites (Jones et al., 1996; Levitt et al., 1997) through the activation of dopamine receptors (Jones et al., 2000; Stanwood and Levitt, 2007). Here we present evidence for a novel role of dopamine in the formation of GABAergic synapses between embryonic precursors of striatal medium spiny neurons, and uncover the underlying signaling mechanisms.

We first demonstrate the presence of dopaminergic $\left(\mathrm{TH}^{+}\right)$ fibers and terminals in the embryonic E17 striatum in vivo, and estimate the in vivo levels of tissue dopamine using HPLC. Moreover, we reveal that dopamine receptors (both $\mathrm{D}_{1}$ Rs and $\mathrm{D}_{2} \mathrm{Rs}$ ) are coexpressed in the large population of neurons within the embryonic striatum. Our experiments further demonstrate that activation of these receptors produces a robust decrease in the number of GABAergic synaptic contacts as indicated by a reduction in colocalization between $\mathrm{GABA}_{\mathrm{A}}$ receptor-positive clusters and VIAAT-1/FM1-43FX-positive presynaptic nerve terminals. Similar type of analysis has been used extensively to study formation of GABAergic synapses (Chih et al., 2005; Dong et al., 2007; Yu et al., 2007). Furthermore, our functional experiments demonstrate that the observed mislocalization of synaptic elements gether with these observations, our experiments suggest that the effects of dopamine on the structure of synaptic contacts may be widespread in the developing striatum as well as in the adult striatum. In addition, given that dopamine receptor activation leads to a reduction in cell-surface levels of $\mathrm{GABA}_{\mathrm{A}}$ receptors, which is concomitant with a reduction in the number of GABAergic synapses, we hypothesize that $\mathrm{GABA}_{\mathrm{A}}$ receptors promote development of GABAergic synapses not only as the "building blocks" of GABAergic synapses, but also through their activity. Indeed, $\mathrm{GABA}_{\mathrm{A}}$ receptor activity has been suggested to play an important role in formation and/or stabilization of synapses in the adult neurons (Li et al., 2005; Chattopadhyaya et al., 2007).

Dopamine-dependent reduction in the levels of $\mathrm{GABA}_{\mathrm{A}}$ receptors expressed at the cell surface, which we demonstrate is due to increased endocytosis of these receptors, and a decrease in GABAergic currents, appear to be preserved in the striatum until adulthood, when $\mathrm{D}_{1}$ Rs activation causes similar effects (FloresHernandez et al., 2000; Hernández-Echeagaray et al., 2007). Moreover, in other brain regions, for example, in the nucleus accumbens (Chen et al., 2006) and hippocampus (Graziane et al., 2009), $D_{2}$ Rs cause a decrease in cell-surface expression and $\mathrm{GABA}_{\mathrm{A}}$ receptor-mediated currents. It is intriguing however, 
that the functionally opposing signaling pathways coupled to $D_{1}$ Rs and $D_{2} R s$, which are clearly segregated to different types of medium spiny neurons in the adult striatum (Surmeier et al., 2007), operate jointly within their embryonic counterparts to produce quantitatively similar changes in $\mathrm{GABA}_{\mathrm{A}}$ receptor surface levels as demonstrated here.

To elucidate the signaling players underpinning this regulation, we first demonstrate that $D_{1}$ Rs decrease the cell-surface expression of $\mathrm{GABA}_{\mathrm{A}}$ receptors and their phosphorylation state through an intracellular signaling pathway involving AC/PKA, ERK1/2, and PP2A (Figs. 6-8). The question remains as to how AC, PP2A, and ERK1/2 can act in concert to cause the observed dephosphorylation and endocytosis of $\mathrm{GABA}_{\mathrm{A}}$ receptors. One possible mechanism is that $D_{1}$ Rs decrease the phosphorylation of $\mathrm{GABA}_{\mathrm{A}}$ receptors through the activity of PP2A (Fig. 8). Indeed this has been shown to occur in other systems (Jovanovic et al., 2004), and PP2A can be activated by $\mathrm{D}_{1}$ Rs through PKAmediated phosphorylation (Ahn et al., 2007). However, PKA is also known to associate with $\mathrm{GABA}_{\mathrm{A}}$ receptors and phosphorylate $\beta$ subunits directly (Brandon et al., 2003). Therefore it seems likely that the balance between these two signaling pathways, possibly mediated by two spatially segregated pools of PKA, will determine the phosphorylation state of $\mathrm{GABA}_{\mathrm{A}}$ receptors, but is this balance critical for the regulation of $\mathrm{GABA}_{\mathrm{A}}$ receptor endocytosis? Although we demonstrate a clear correlation between $\mathrm{D}_{1} \mathrm{R}$ - and $\mathrm{D}_{2} \mathrm{R}$-dependent reduction in both $\mathrm{GABA}_{\mathrm{A}}$ receptor cell-surface expression and phosphorylation state, it must be noted that the former is long lasting, while the latter is only transient. Thus, the receptor dephosphorylation may be required only for the initiation of endocytosis, but not for the subsequent maintenance of the appropriate levels of $\mathrm{GABA}_{\mathrm{A}}$ receptors at the cell surface. In the adult tissue, dynamin-dependent endocytosis of $\mathrm{GABA}_{\mathrm{A}}$ receptors has been reported to depend on their phosphorylation state (Kittler et al., 2000, 2005, 2008). Similar phosphorylation-dependent mechanisms have been shown to underlie $\mathrm{D}_{3} \mathrm{R}$-induced internalization of $\mathrm{GABA}_{\mathrm{A}}$ receptors in the adult nucleus accumbens (Chen et al., 2006).

The role of ERK1 and ERK2 kinases in $\mathrm{D}_{1} \mathrm{R}$-dependent regulation of surface $\mathrm{GABA}_{\mathrm{A}}$ receptors is intriguing. As schematically depicted in the Figure 8, D1Rs may regulate the activity of ERK1 and ERK2 kinases through an inhibition of the striatal-enriched tyrosine phosphatase STEP (Paul et al., 2000; Valjent et al., 2005; Braithwaite et al., 2006b), which was previously shown to dephosphorylate and inactivate ERK kinases (Braithwaite et al., 2006b; Venkitaramani et al., 2009). D 1 R-triggered increase of ERK activity may also be mediated through DARPP-32-dependent and -independent mechanisms (Gerfen et al., 2008). Namely, $D_{1}$ Rs can lead to an activation of DARPP-32 through a PKA- and/or PP2A-dependent signaling mechanism (Svenningsson et al., 2004) resulting in a decrease in the activity of PP1. This could further lead to an increase in STEP phosphorylation, which is concomitant with an inhibition of its activity and consequent stimulation of ERK kinases. Additionally, DARPP-32 appears to be required for an increase in phosphorylation of MEK, a dual specificity kinase that directly phosphorylates and thus activates ERK kinases (Valjent et al., 2005). A possible DARPP-32-independent mechanism may occur through a PKA-dependent phosphorylation of STEP, which would decrease its activity and consequently stimulate the activity of ERK kinases (Braithwaite et al., 2006b). Although ERK kinases can be activated in a number of ways by $D_{1}$ Rs, it is unclear how this activation impinges on the regulation of surface $\mathrm{GABA}_{\mathrm{A}}$ receptors. We hypothesize that activated ERK kinases may stimulate PP2A (Belcher et al., 2005) to dephosphorylate $\mathrm{GABA}_{\mathrm{A}}$ receptors and trig- ger their internalization. In support of this hypothesis is the observation that inhibition of ERK kinases by PD 98509 not only abolishes dephosphorylation of $\beta$ subunits by D1Rs, but also increases their phosphorylation on its own. A possible role of STEP in $\mathrm{GABA}_{\mathrm{A}}$ receptor regulation is interesting since it has been previously shown to regulate endocytosis of both NMDA and AMPA receptors (Braithwaite et al., 2006a; Zhang et al., 2008).

We have demonstrated that $\mathrm{D}_{2} \mathrm{R}$-dependent decreases in both phosphorylation and cell-surface expression of $\mathrm{GABA}_{\mathrm{A}}$ receptor are mediated by PP1 (Figs. $6-8$ ). $\mathrm{D}_{2}$ Rs, by virtue of their ability to decrease PKA activity through inhibition of AC, may lead to a dephosphorylation of DARPP-32 (Nishi et al., 1997). At the same time, reduced activity of PKA may lead to a reduction in the activity of PP2A (Ahn et al., 2007) resulting in an increase in phosphorylation of DARPP-32 at the phosphorylation site, which converts this protein into an inhibitor of PKA (Bibb et al., 1999). The overall effect of these changes may be an increase in the activity of PP1 and a corollary inhibition of PKA. This may lead to a decrease in phosphorylation of $\mathrm{GABA}_{\mathrm{A}}$ receptors by $\mathrm{PP} 1$ as shown previously (Kanematsu et al., 2006). Thus, DARPP-32 and STEP may act as signaling integrators of $\mathrm{D}_{1} \mathrm{R}-$ and $\mathrm{D}_{2} \mathrm{R}-$ signaling pathways regulating phosphorylation and surface expression of $\mathrm{GABA}_{\mathrm{A}}$ receptors in the embryonic striatal neurons.

In summary, tonic activity of dopamine receptors regulates formation of GABAergic synapses in the developing striatum, at least in part, through phosphorylation-dependent changes in cell-surface expression of $\mathrm{GABA}_{\mathrm{A}}$ receptors. The effects of dopamine and consequences of dopamine-depletion on the structure of GABAergic synapses in the adult striatum await future investigations.

\section{References}

Ahn JH, McAvoy T, Rakhilin SV, Nishi A, Greengard P, Nairn AC (2007) Protein kinase A activates protein phosphatase $2 \mathrm{~A}$ by phosphorylation of the B56delta subunit. Proc Natl Acad Sci U S A 104:2979-2984.

Aizman O, Brismar H, Uhlén P, Zettergren E, Levey AI, Forssberg H, Greengard P, Aperia A (2000) Anatomical and physiological evidence for D1 and D2 dopamine receptor colocalization in neostriatal neurons. Nat Neurosci 3:226-230.

Aosaki T, Kiuchi K, Kawaguchi Y (1998) Dopamine $D_{1}$-like receptor activation excites rat striatal large aspiny neurons in vitro. J Neurosci 18:5180-5190.

Awad JA, Johnson RA, Jakobs KH, Schultz G (1983) Interactions of forskolin and adenylate cyclase. Effects on substrate kinetics and protection against inactivation by heat and N-ethylmaleimide. J Biol Chem 258:2960-2965.

Bedford FK, Kittler JT, Muller E, Thomas P, Uren JM, Merlo D, Wisden W, Triller A, Smart TG, Moss SJ (2001) GABA(A) receptor cell surface number and subunit stability are regulated by the ubiquitin-like protein Plic-1. Nat Neurosci 4:908-916.

Belcher SM, Le HH, Spurling L, Wong JK (2005) Rapid estrogenic regulation of extracellular signal- regulated kinase $1 / 2$ signaling in cerebellar granule cells involves a $\mathrm{G}$ protein- and protein kinase A-dependent mechanism and intracellular activation of protein phosphatase 2A. Endocrinology 146:5397-5406.

Bibb JA, Snyder GL, Nishi A, Yan Z, Meijer L, Fienberg AA, Tsai LH, Kwon YT, Girault JA, Czernik AJ, Huganir RL, Hemmings HC Jr, Nairn AC, Greengard P (1999) Phosphorylation of DARPP-32 by Cdk5 modulates dopamine signalling in neurons. Nature 402:669-671.

Biggs CS, Pearce BR, Fowler LJ, Whitton PS (1992) Regional effects of sodium valproate on extracellular concentrations of 5-hydroxytryptamine, dopamine, and their metabolites in the rat brain: an in vivo microdialysis study. J Neurochem 59:1702-1708.

Bockaert J, Gabrion J, Sladeczek F, Pin JP, Recasens M, Sebben M, Kemp D, Dumuis A, Weiss S (1986) Primary culture of striatal neurons: a model of choice for pharmacological and biochemical studies of neurotransmitter receptors. J Physiol (Paris) 81:219-227.

Bracci E, Centonze D, Bernardi G, Calabresi P (2002) Dopamine excites fast-spiking interneurons in the striatum. J Neurophysiol 87:2190-2194. 
Braithwaite SP, Adkisson M, Leung J, Nava A, Masterson B, Urfer R, Oksenberg D, Nikolich K (2006a) Regulation of NMDA receptor trafficking and function by striatal-enriched tyrosine phosphatase (STEP). Eur J Neurosci 23:2847-2856

Braithwaite SP, Paul S, Nairn AC, Lombroso PJ (2006b) Synaptic plasticity: one STEP at a time. Trends Neurosci 29:452-458.

Brandon NJ, Jovanovic JN, Moss SJ (2002) Multiple roles of protein kinases in the modulation of gamma-aminobutyric acid(A) receptor function and cell surface expression. Pharmacol Ther 94:113-122.

Brandon NJ, Jovanovic JN, Colledge M, Kittler JT, Brandon JM, Scott JD, Moss SJ (2003) A-kinase anchoring protein 79/150 facilitates the phosphorylation of $\mathrm{GABA}(\mathrm{A})$ receptors by cAMP-dependent protein kinase via selective interaction with receptor beta subunits. Mol Cell Neurosci 22:87-97.

Brumback AC, Lieber JL, Angleson JK, Betz WJ (2004) Using FM1-43 to study neuropeptide granule dynamics and exocytosis. Methods 33:287-294

Chattopadhyaya B, Di Cristo G, Wu CZ, Knott G, Kuhlman S, Fu Y, Palmiter RD, Huang ZJ (2007) GAD67-mediated GABA synthesis and signaling regulate inhibitory synaptic innervation in the visual cortex. Neuron 54:889-903.

Chen G, Kittler JT, Moss SJ, Yan Z (2006) Dopamine $\mathrm{D}_{3}$ receptors regulate $\mathrm{GABA}_{\mathrm{A}}$ receptor function through a phospho-dependent endocytosis mechanism in nucleus accumbens. J Neurosci 26:2513-2521.

Chih B, Engelman H, Scheiffele P (2005) Control of excitatory and inhibitory synapse formation by neuroligins. Science 307:1324-1328.

Christie SB, Li RW, Miralles CP, Riquelme R, Yang BY, Charych E, WendouYu, Daniels SB, Cantino ME, De Blas AL (2002a) Synaptic and extrasynaptic GABAA receptor and gephyrin clusters. Prog Brain Res 136:157-180.

Christie SB, Miralles CP, De Blas AL (2002b) GABAergic innervation organizes synaptic and extrasynaptic $\mathrm{GABA}_{\mathrm{A}}$ receptor clustering in cultured hippocampal neurons. J Neurosci 22:684-697.

Cohen P, Alemany S, Hemmings BA, Resink TJ, Strålfors P, Tung HY (1988) Protein phosphatase-1 and protein phosphatase-2A from rabbit skeletal muscle. Methods Enzymol 159:390-408.

Connolly CN, Kittler JT, Thomas P, Uren JM, Brandon NJ, Smart TG, Moss SJ (1999) Cell surface stability of gamma-aminobutyric acid type A receptors. Dependence on protein kinase $\mathrm{C}$ activity and subunit composition. J Biol Chem 274:36565-36572.

Day M, Wang Z, Ding J, An X, Ingham CA, Shering AF, Wokosin D, Ilijic E, Sun Z, Sampson AR, Mugnaini E, Deutch AY, Sesack SR, Arbuthnott GW, Surmeier DJ (2006) Selective elimination of glutamatergic synapses on striatopallidal neurons in Parkinson disease models. Nat Neurosci 9:251-259.

Desdouits F, Siciliano JC, Nairn AC, Greengard P, Girault JA (1998) Dephosphorylation of Ser-137 in DARPP-32 by protein phosphatases 2A and 2C: different roles in vitro and in striatonigral neurons. Biochem J 330:211-216.

Dong N, Qi J, Chen G (2007) Molecular reconstitution of functional GABAergic synapses with expression of neuroligin-2 and GABAA receptors. Mol Cell Neurosci 35:14-23.

Dumoulin A, Rostaing P, Bedet C, Lévi S, Isambert MF, Henry JP, Triller A, Gasnier B (1999) Presence of the vesicular inhibitory amino acid transporter in GABAergic and glycinergic synaptic terminal boutons. J Cell Sci 112:811-823.

Dumoulin A, Lévi S, Riveau B, Gasnier B, Triller A (2000) Formation of mixed glycine and GABAergic synapses in cultured spinal cord neurons. Eur J Neurosci 12:3883-3892.

Falk T, Zhang S, Erbe EL, Sherman SJ (2006) Neurochemical and electrophysiological characteristics of rat striatal neurons in primary culture. J Comp Neurol 494:275-289.

Flores-Hernandez J, Hernandez S, Snyder GL, Yan Z, Fienberg AA, Moss SJ, Greengard P, Surmeier DJ (2000) D(1) dopamine receptor activation reduces $\mathrm{GABA}(\mathrm{A})$ receptor currents in neostriatal neurons through a PKA/DARPP-32/PP1 signaling cascade. J Neurophysiol 83:2996-3004.

Fujiyama F, Fritschy JM, Stephenson FA, Bolam JP (2000) Synaptic localization of $\operatorname{GABA}(\mathrm{A})$ receptor subunits in the striatum of the rat. J Comp Neurol 416:158-172.

Gates MA, Torres EM, White A, Fricker-Gates RA, Dunnett SB (2006) Reexamining the ontogeny of substantia nigra dopamine neurons. Eur J Neurosci 23:1384-1390.
Gerfen CR, Paletzki R, Worley P (2008) Differences between dorsal and ventral striatum in Drdla dopamine receptor coupling of dopamine- and cAMP-regulated phosphoprotein-32 to activation of extracellular signalregulated kinase. J Neurosci 28:7113-7120.

Girault JA, Hemmings HC Jr, Williams KR, Nairn AC, Greengard P (1989) Phosphorylation of DARPP-32, a dopa. J Biol Chem 264:21748-21759.

Gout I, Dhand R, Hiles ID, Fry MJ, Panayotou G, Das P, Truong O, Totty NF, Hsuan J, Booker GW (1993) The GTPase dynamin binds to and is activated by a subset of SH3 domains. Cell 75:25-36.

Grabs D, Slepnev VI, Songyang Z, David C, Lynch M, Cantley LC, De Camilli P (1997) The SH3 domain of amphiphysin binds the proline-rich domain of dynamin at a single site that defines a new SH3 binding consensus sequence. J Biol Chem 272:13419-13425.

Graziane NM, Yuen EY, Yan Z (2009) Dopamine D4 receptors regulate GABAA receptor trafficking via an actin/cofilin/myosin-dependent mechanism. J Biol Chem 284:8329-8336.

Greengard P (2001) The neurobiology of slow synaptic transmission. Science 294:1024-1030.

Guzmán JN, Hernández A, Galarraga E, Tapia D, Laville A, Vergara R, Aceves J, Bargas J (2003) Dopaminergic modulation of axon collaterals interconnecting spiny neurons of the rat striatum. J Neurosci 23:8931-8940.

Hernández-Echeagaray E, Cepeda C, Ariano MA, Lobo MK, Sibley DR, Levine MS (2007) Dopamine reduction of GABA currents in striatal medium-sized spiny neurons is mediated principally by the $\mathrm{D}(1)$ receptor subtype. Neurochem Res 32:229-240.

Huttner WB, DeGennaro LJ, Greengard P (1981) Differential phosphorylation of multiple sites in purified protein I by cyclic AMP-dependent and calcium-dependent protein kinases. J Biol Chem 256:1482-1488.

Ingebritsen TS, Stewart AA, Cohen P (1983) The protein phosphatases involved in cellular regulation. 6 . Measurement of type- 1 and type- 2 protein phosphatases in extracts of mammalian tissues; an assessment of their physiological roles. Eur J Biochem 132:297-307.

Iwakura Y, Nawa H, Sora I, Chao MV (2008) Dopamine D1 receptorinduced signaling through TrkB receptors in striatal neurons. J Biol Chem 283:15799-15806.

Jones L, Fischer I, Levitt P (1996) Nonuniform alteration of dendritic development in the cerebral cortex following prenatal cocaine exposure. Cereb Cortex 6:431-445.

Jones LB, Stanwood GD, Reinoso BS, Washington RA, Wang HY, Friedman $\mathrm{E}$, Levitt P (2000) In utero cocaine-induced dysfunction of dopamine $\mathrm{D}_{1}$ receptor signaling and abnormal differentiation of cerebral cortical neurons. J Neurosci 20:4606-4614.

Jovanovic JN, Thomas P, Kittler JT, Smart TG, Moss SJ (2004) Brainderived neurotrophic factor modulates fast synaptic inhibition by regulating $\mathrm{GABA}_{\mathrm{A}}$ receptor phosphorylation, activity, and cell-surface stability. J Neurosci 24:522-530.

Kaczmarek LK, Jennings KR, Strumwasser F, Nairn AC, Walter U, Wilson FD, Greengard P (1980) Microinjection of catalytic subunit of cyclic AMPdependent protein kinase enhances calcium action potentials of bag cell neurons in cell culture. Proc Natl Acad Sci U S A 77:7487-7491.

Kanematsu T, Yasunaga A, Mizoguchi Y, Kuratani A, Kittler JT, Jovanovic JN, Takenaka K, Nakayama KI, Fukami K, Takenawa T, Moss SJ, Nabekura J, Hirata M (2006) Modulation of GABA(A) receptor phosphorylation and membrane trafficking by phospholipase C-related inactive protein/protein phosphatase 1 and $2 \mathrm{~A}$ signaling complex underlying brain-derived neurotrophic factor-dependent regulation of GABAergic inhibition. J Biol Chem 281:22180-22189.

Kay AR, Alfonso A, Alford S, Cline HT, Holgado AM, Sakmann B, Snitsarev VA, Stricker TP, Takahashi M, Wu LG (1999) Imaging synaptic activity in intact brain and slices with FM1-43 in C. elegans, lamprey, and rat. Neuron 24:809-817.

Kittler JT, Moss SJ (2003) Modulation of GABAA receptor activity by phosphorylation and receptor trafficking: implications for the efficacy of synaptic inhibition. Curr Opin Neurobiol 13:341-347.

Kittler JT, Delmas P, Jovanovic JN, Brown DA, Smart TG, Moss SJ (2000) Constitutive endocytosis of $\mathrm{GABA}_{\mathrm{A}}$ receptors by an association with the adaptin AP2 complex modulates inhibitory synaptic currents in hippocampal neurons. J Neurosci 20:7972-7977.

Kittler JT, Thomas P, Tretter V, Bogdanov YD, Haucke V, Smart TG, Moss SJ (2004) Huntingtin-associated protein 1 regulates inhibitory synaptic transmission by modulating gamma-aminobutyric acid type A receptor membrane trafficking. Proc Natl Acad Sci U S A 101:12736-12741. 
Kittler JT, Chen G, Honing S, Bogdanov Y, McAinsh K, Arancibia-Carcamo IL, Jovanovic JN, Pangalos MN, Haucke V, Yan Z, Moss SJ (2005) Phospho-dependent binding of the clathrin AP2 adaptor complex to GABAA receptors regulates the efficacy of inhibitory synaptic transmission. Proc Natl Acad Sci U S A 102:14871-14876.

Kittler JT, Chen G, Kukhtina V, Vahedi-Faridi A, Gu Z, Tretter V, Smith KR, McAinsh K, Arancibia-Carcamo IL, Saenger W, Haucke V, Yan Z, Moss SJ (2008) Regulation of synaptic inhibition by phospho-dependent binding of the AP2 complex to a YECL motif in the GABAA receptor gamma2 subunit. Proc Natl Acad Sci U S A 105:3616-3621.

Kobayashi E, Ando K, Nakano H, Iida T, Ohno H, Morimoto M, Tamaoki T (1989) Calphostins (UCN-1028), novel and specific inhibitors of protein kinase C. I. Fermentation, isolation, physico-chemical properties and biological activities. J Antibiot (Tokyo) 42:1470-1474.

Laurenza A, Sutkowski EM, Seamon KB (1989) Forskolin: a specific stimulator of adenylyl cyclase or a diterpene with multiple sites of action? Trends Pharmacol Sci 10:442-447.

Levitt P, Harvey JA, Friedman E, Simansky K, Murphy EH (1997) New evidence for neurotransmitter influences on brain development. Trends Neurosci 20:269-274.

Li RW, Yu W, Christie S, Miralles CP, Bai J, Loturco JJ, De Blas AL (2005) Disruption of postsynaptic GABA receptor clusters leads to decreased GABAergic innervation of pyramidal neurons. J Neurochem 95:756-770.

Lissin DV, Gomperts SN, Carroll RC, Christine CW, Kalman D, Kitamura M, Hardy S, Nicoll RA, Malenka RC, von Zastrow M (1998) Activity differentially regulates the surface expression of synaptic AMPA and NMDA glutamate receptors. Proc Natl Acad Sci U S A 95:7097-7102.

Lu H, Lim B, Poo MM (2009) Cocaine exposure in utero alters synaptic plasticity in the medial prefrontal cortex of postnatal rats. J Neurosci 29:12664-12674.

Mallet N, Le Moine C, Charpier S, Gonon F (2005) Feedforward inhibition of projection neurons by fast-spiking GABA interneurons in the rat striatum in vivo. J Neurosci 25:3857-3869.

Marks B, McMahon HT (1998) Calcium triggers calcineurin-dependent synaptic vesicle recycling in mammalian nerve terminals. Curr Biol 8:740-749.

McDonald BJ, Moss SJ (1997) Conserved phosphorylation of the intracellular domains of GABA(A) receptor beta 2 and beta 3 subunits by cAMPdependent protein kinase, cGMP-dependent protein kinase protein kinase $\mathrm{C}$ and $\mathrm{Ca} 2+/$ calmodulin type II-dependent protein kinase. Neuropharmacology 36:1377-1385.

Missale C, Nash SR, Robinson SW, Jaber M, Caron MG (1998) Dopamine receptors: from structure to function. Physiol Rev 78:189-225.

Nairn AC, Sihra TS, Andjus P, Craig A-M, Miyawaki A, Kloppenburg P, Lin Z, Pouzat C (1995) Rapid purification of protein phosphatase-2B (calcineurin) from rat forebrain. Neuroprotocols 6:105-107.

Nishi A, Snyder GL, Greengard P (1997) Bidirectional regulation of DARPP-32 phosphorylation by dopamine. J Neurosci 17:8147-8155.

Noel J, Ralph GS, Pickard L, Williams J, Molnar E, Uney JB, Collingridge GL, Henley JM (1999) Surface expression of AMPA receptors in hippocampal neurons is regulated by an NSF-dependent mechanism. Neuron 23:365-376.

Nong Y, Huang YQ, Ju W, Kalia LV, Ahmadian G, Wang YT, Salter MW (2003) Glycine binding primes NMDA receptor internalization. Nature 422:302-307.

Nusser Z, Cull-Candy S, Farrant M (1997) Differences in synaptic GABA(A) receptor number underlie variation in GABA mini amplitude. Neuron 19:697-709.

Nusser Z, Hájos N, Somogyi P, Mody I (1998) Increased number of synaptic GABA(A) receptors underlies potentiation at hippocampal inhibitory synapses. Nature 395:172-177.

Paul S, Snyder GL, Yokakura H, Picciotto MR, Nairn AC, Lombroso PJ (2000) The dopamine $/ D_{1}$ receptor mediates the phosphorylation and inactivation of the protein tyrosine phosphatase STEP via a PKAdependent pathway. J Neurosci 20:5630-5638.

Sara Y, Mozhayeva MG, Liu X, Kavalali ET (2002) Fast vesicle recycling supports neurotransmission during sustained stimulation at hippocampal synapses. J Neurosci 22:1608-1617.

Seeman P, Van Tol HH (1994) Dopamine receptor pharmacology. Trends Pharmacol Sci 15:264-270.

Sefton BM (2001) Overview of protein phosphorylation. Curr Protoc Cell Biol 14.1.

Specht LA, Pickel VM, Joh TH, Reis DJ (1981) Light-microscopic immuno- cytochemical localization of tyrosine hydroxylase in prenatal rat brain. I. Early ontogeny. J Comp Neurol 199:233-253.

Stampwala SS, Bunge RH, Hurley TR, Willmer NE, Brankiewicz AJ, Steinman CE, Smitka TA, French JC (1983) Novel antitumor agents CI-920, PD 113,270 and PD 113,271. II. Isolation and characterization. J Antibiot (Tokyo) 36:1601-1605

Stanwood GD, Levitt P (2007) Prenatal exposure to cocaine produces unique developmental and long-term adaptive changes in dopamine $\mathrm{D}_{1}$ receptor activity and subcellular distribution. J Neurosci 27:152-157.

Surmeier DJ, Eberwine J, Wilson CJ, Cao Y, Stefani A, Kitai ST (1992) Dopamine receptor subtypes colocalize in rat striatonigral neurons. Proc Natl Acad Sci U S A 89:10178-10182.

Surmeier DJ, Bargas J, Hemmings HC Jr, Nairn AC, Greengard P (1995) Modulation of calcium currents by a D1 dopaminergic protein kinase/ phosphatase cascade in rat neostriatal neurons. Neuron 14:385-397.

Surmeier DJ, Ding J, Day M, Wang Z, Shen W (2007) D1 and D2 dopaminereceptor modulation of striatal glutamatergic signaling in striatal medium spiny neurons. Trends Neurosci 30:228-235.

Svenningsson P, Nishi A, Fisone G, Girault JA, Nairn AC, Greengard P (2004) DARPP-32: an integrator of neurotransmission. Annu Rev Pharmacol Toxicol 44:269-296.

Tang TS, Bezprozvanny I (2004) Dopamine receptor-mediated Ca(2+) signaling in striatal medium spiny neurons. J Biol Chem 279:42082-42094.

Taverna S, Ilijic E, Surmeier DJ (2008) Recurrent collateral connections of striatal medium spiny neurons are disrupted in models of Parkinson's disease. J Neurosci 28:5504-5512.

Tepper JM, Bolam JP (2004) Functional diversity and specificity of neostriatal interneurons. Curr Opin Neurobiol 14:685-692.

Terunuma M, Jang IS, Ha SH, Kittler JT, Kanematsu T, Jovanovic JN, Nakayama KI, Akaike N, Ryu SH, Moss SJ, Hirata M (2004) GABA receptor phospho-dependent modulation is regulated by phospholipase C-related inactive protein type 1 , a novel protein phosphatase 1 anchoring protein. J Neurosci 24:7074-7084.

Thomas P, Mortensen M, Hosie AM, Smart TG (2005) Dynamic mobility of functional GABAA receptors at inhibitory synapses. Nat Neurosci 8:889-897.

Ting JT, Kelley BG, Sullivan JM (2006) Synaptotagmin IV does not alter excitatory fast synaptic transmission or fusion pore kinetics in mammalian CNS neurons. J Neurosci 26:372-380.

Valjent E, Pascoli V, Svenningsson P, Paul S, Enslen H, Corvol JC, Stipanovich A, Caboche J, Lombroso PJ, Nairn AC, Greengard P, Hervé D, Girault JA (2005) Regulation of a protein phosphatase cascade allows convergent dopamine and glutamate signals to activate ERK in the striatum. Proc Natl Acad Sci U S A 102:491-496.

van Rijnsoever C, Sidler C, Fritschy JM (2005) Internalized GABA-receptor subunits are transferred to an intracellular pool associated with the postsynaptic density. Eur J Neurosci 21:327-338.

Venkitaramani DV, Paul S, Zhang Y, Kurup P, Ding L, Tressler L, Allen M, Sacca R, Picciotto MR, Lombroso PJ (2009) Knockout of STriatal Enriched protein tyrosine Phosphatase in mice results in increased ERK1/2 phosphorylation. Synapse 63:69-81.

Ventimiglia R, Lindsay RM (1998) Rat striatal neurons in low-density, serum-free culture. In: Culturing nerve cells (Banker G, Goslin K, eds), pp 371-393. Cambridge, MA: MIT.

Voorn P, Kalsbeek A, Jorritsma-Byham B, Groenewegen HJ (1988) The preand postnatal development of the dopaminergic cell groups in the ventral mesencephalon and the dopaminergic innervation of the striatum of the rat. Neuroscience 25:857-887.

Walaas SI, Greengard P (1991) Protein phosphorylation and neuronal function. Pharmacol Rev 43:299-349.

Whiting PJ (2003) GABA-A receptor subtypes in the brain: a paradigm for CNS drug discovery? Drug Discov Today 8:445-450.

Yan Z, Surmeier DJ (1997) D5 dopamine receptors enhance Zn2+sensitive GABA(A) currents in striatal cholinergic interneurons through a PKA/PP1 cascade. Neuron 19:1115-1126.

Yu W, Jiang M, Miralles CP, Li RW, Chen G, de Blas AL (2007) Gephyrin clustering is required for the stability of GABAergic synapses. Mol Cell Neurosci 36:484-500.

Zhang Y, Venkitaramani DV, Gladding CM, Zhang Y, Kurup P, Molnar E, Collingridge GL, Lombroso PJ (2008) The tyrosine phosphatase STEP mediates AMPA receptor endocytosis after metabotropic glutamate receptor stimulation. J Neurosci 28:10561-10566. 